\title{
BIOPOLÍTICA Y FILOSOFÍA: EL PENSAMIENTO CONTEMPORÁNEO Y EL CONTROL SOBRE LA VIDA (un diálogo con Marco Díaz Marsá)
}

\author{
Simón RoYo HeRnández \\ Investigador Postdoc. (UNED)
}

Resumen: El presente trabajo pretende ser un diálogo agonístico en fructífera polémica con el artículo titulado "De la nuda vida como forma de vida o de la aporía de la política moderna. Un estudio a partir de Giorgio Agamben», del profesor Marco Díaz Marsá, trabajo publicado en ésta misma revista. La primera parte de éste artículo es subsidiaria, por tanto, del trabajo mencionado y no puede ser leída y comprendida sin tenerlo en consideración. La segunda parte incide en una vía secundaria y se centra en el problema de la interpretación de la Política de Aristóteles en una dirección contrapuesta a la que pensamos inscrita en la problemática de la biopolítica analizada con anterioridad. En la tercera parte empero, trataremos de ofrecer la propia postura en contraposición a la críticamente expuesta con anterioridad de modo que pueda leerse tanto de modo independiente como de modo subsidiario a lo antecedente. $\mathrm{Al}$ no disponer de la paginación del artículö comentado realizamos su recorrido de un modo lineal utilizando el formato ensayo para tal menester, pero con el apoyo de las notas que colocamos al final del mismo así como de las referencias indicadas, no excesivamente numerosas pero sí selectamente escogidas que van en el cuerpo principal del texto. 


\section{PRIMERA PARTE:}

\section{Biopolítica y filosofía. Un diálogo con Marco Díaz Marsá}

El profesor Marsá nos sitúa en lo que cree que constituye la aporía fundamental de la política moderna a partir de las reflexiones que lleva a cabo en su reproblematización del pensamiento de Giorgio Agamben, Hannah Arendt y Michel Foucault. Para ello detecta primero una discontinuidad entre la política antigua y la política moderna, que quedaría ejemplificada en la distinción entre zoé y bios; pero de modo que la naturalización o animalización de la palítica por un lado y la politización de la vida, por otro, resultan conjuntamente el rasgo político esencial de la política moderna, constituida como biopolítica. En tal caso estaríamos ante el hecho de que el desarrollo del totalitarismo nacionalsocialista que, tergiversando el darwinismo y la lingüística, quiso instaurar una eugenesia en consonancia con ciertos pasajes de la República de Platón habría encontrado su máximo cumplimiento en nuestros días; luego viviríamos bajo un férreo sistema de dominación micropolítica y macropolítica que no cabría mesopolíticamente calificar de democracia: "Hay que notar que, si esto es asi, totalitarismo y democracia funcionan como las dos caras de una misma politica centrada sobre la vida». La aporía de la política moderna presentada nos situaría entonces en una rememoración del protoanarquismo que La Boétie compuso en el siglo XVI, su "Discurso sobre la servidumbre voluntaria", en el cual ya aparece la aporía específica de la modernidad que señala Agamben, la cual "consiste en aventurar la libertad y la felicidad de los hombres en el lugar mismo - la nuda vida-que sellaba su servidumbren, algo que un siglo más tarde repensará y señalará Spinoza. Para éste último la dominación es resultado de la lucha de los propios cuerpos dominados por su servidumbre, pues considera que los dominados no son seres pasivos, medios de la voluntad de sus amos, sino seres plenamente activos. Los dominados lo serán mientras luchen por su esclavitud, pero ningún destino los mantiene atados a ella, sino una concatenación de fuerzas, una interacción de causas que es posible conocer y modificar. Nazismo y fascismo son en tal caso "actuales" $y$ el vitalismo, según Agamben, el lugar de la dominación confundido con el de la liberación. Un corolario pesimista en el que todo es leído como mecanismo de dominación y tanto el Estado como el Mercado, como cualesquiera determinaciones de la vida burguesa (que se sobrelleva en alto standing) sólo se revolucio-

'La Boétie «Discours de la servitude volontaire" (1574). En:

http://perso.orange.fr/libertaire/archive/2000/227-avr/boetie.htm 
nará micropolíticamente, mediante personales impugnaciones de degeneración moral y trangresión individual.

En tal punto el profesor Marsá recoge aquello que Deleuze acusaba en Foucault, al decir que el segundo "se ahogaba», "le faltaba lo posible». Se construye primero en la teoría un habitáculo sin afueras, todo voluntad de poder, para luego comenzar a padecer problemas con la respiración del propio aire mefítico. Luego la corrección a la que lo posible nos empuja reside en abandonar un corolario político del existencialismo nihilista y reconocer que el poder del intervencionismo social a través de las instituciones del Estado no sólo se ejerce en nombre de la vida para implicar a los hombres jóvenes en la carnicería de la guerra, cosa que es cierta, sino que también es el que, lejos de la misantropía que reactualiza el malthusianismo, en nombre de la vida se han podido realizar sistemas de seguridad social para proteger la salud, sistemas educativos para promover el saber, sistemas judiciales para proteger los derechos, así como sistemas arquitectónicos para poder habitar en las ciudades. Todos ellos muy problemáticos, cierto, pero no sólo orientados a la dominación, ya que disponer de penicilina, de agua potable o de electricidad, por poco progresista que se sea, no es algo de lo que quepa hablar de prescindir.

Cuando Giorgio Agamben indica en sus Profanaciones ${ }^{2}$ que el acto político de profanar las esferas sacrales o separadas consiste en restituir al uso público y común lo que le había sido sustraído, nos ofrece un nuevo programa abstracto de secularización del que la casuística concreta puede hacerse cargo; bien para mostrar su virtualidad absurda, bien para mostrar su virtualidad en lo posible. Restituir a los niños al uso público común y restaurar una supuesta pederastia universal que nos hubiese sido malignamente sustraída pudiera muy bien ser una operación política que se apoyase en Agamben. El trasero de los niños y la vagina de las niñas quedaría así expuesto al dominio público con el cual el anarquismo ambiguo de la postmodernidad postcapitalista, permite, que la izquierda caviar, libere sin limites sus deseos inconfesables y descalifique toda Ética como reaccionarismo conservador y puritano platonizante al que se opondría la nueva teoría queer que pretende remitirse a Foucault ${ }^{3}$ y justificar la pedofilia. La realiza-

${ }^{2}$ Giorgio Agamben Profanaciones. Editorial Anagrama. Barcelona 2005. «Elogio de la profanación", págs.95-121.

${ }^{3}$ "Aunque la conducta sexual aceptable se defina con mayor amplitud, muchos de los viejos prejuicios siguen vigentes y siempre se están gestando nuevas crisis. Las escenas de histeria colec- 
ción de los deseos subjetivos resulta entonces no otra cosa que voluntad de poder encubierta de eficiencia pragmática. Otra cosa sería la concreción de la operación política de profanar como una operación política posible pero costosa como la que pudiera consistir en rechazar el principio de propiedad negándose a pagar la hipoteca de la propia vivienda, ocupando una vacía o proclamándose objetor fiscal. Resulta paradójico que el segundo caso pudiera ser el que más problemas y costos sociales devengaría para el infractor, al que se le enviaría inmediatamente la policía, se le embargaría el piso o se le encausaría como defraudador fiscal. No se nos entienda mal. Quienes tenemos hijos vemos el primer caso como una aberración de tal magnitud que estamos dispuestos a profanarle la cara al primer degenerado que amenazase a nuestra descendencia, hasta el punto de que ninguna corporación dermoestética pudiera restituirle la fachada.

Si la gran actitud de restitución de los usos al dominio público de Agamben tiene como ejemplo el juego de un gato con un ovillo de lana en detrimento de su instinto de caza, difícilmente podrá salir Argentina del marasmo como recetas de tales características. Insistimos por tanto en que además de medios sin fin tengan que arbitrarse medios no teleológicos pero sí con finalidad, en el sentido de objetivos a cumplir, para que pueda hablarse de proyecto político alguno, al menos Deleuze indicaba en los 80, en Mil Mesetas, que esa era la tarea y nadie a sido capaz de realizarla. ¿ No será una quimera?:

«Se puede predecir que los próximos problemas de la economía, que consisten en volver a formar capital en relación con nuevos recursos (petróleo marino, nódulos metálicos, materias alimentarias) no sólo exigirán una redistribución del mundo que movilizará la máquina de guerra mundial y opondrá sus partes en función de los nuevos objetivos; también se asistirá probablemente a la formación o reconstitución de conjuntos minoritarios, en relación con las regiones concernidas (...). Si las minorías no constituyen Estados viables, cultural, política, económicamente, es porque ni la formaEstado, ni la axiomática del capital, ni la cultura correspondiente les convienen (...). Al mismo tiempo el problema de las minorías es más bien aca-

tiva respecto a los paidofilos convictos e incluso a los sospechosos de paidofilia, revelan el lado aterrador del poder de la gente. Freud descubrió la sexualidad infantil, pero este no es un tema que las sociedades de fines del siglo XX pueda discutir racionalmente». T.Spargo Foucault y la teoría queer, Barcelona, Gedisa, 2004, págs. 10-11. 
bar con el capitalismo, redefinir el socialismo, constituir una máquina de guerra capaz de responder a la máquina de guerra mundial, con otros medios" $"$.

Luego no sólo se trata de destrucción, no sólo se trata de destruir el capitalismo, sino también de construcción, de "redefinir el socialismo", no sólo se trata de deconstruir lo subsumido sino sobre todo de "constituir una máquina de guerra capaz de responder a la máquina de guerra mundial». Se trata entonces de, nada más y nada menos, que constituir organizaciones capaces de hacer frente al capitalismo, pero "con otros medios". Y es en esos otros medios donde estriba el problema. ¿Cómo hacer frente a una máquina de matar sin matar? ¿Cómo enfrentarse a los asesinos sin convertirse en asesino? ¿Cómo organizar un mercado que no sea capitalismo? ¿Cómo llevar a cabo una política y forjar una sociedad que no sean las correspondientes ni al capitalismo ni al Estado? No se pueden sacar medios de la chistera, hay que usar los realmente existentes en cada momento al tiempo que se apoya el surgimiento de otros nuevos.

Si el pensamiento es una forma de vida que implica tanto a bios como zoé entonces la muerte de Sócrates resulta ejemplar, así como pertinente entonces un análisis ad hominem no insultante para dirimir si los que hacen profesión de fe franciscana, como Agamben o Negri, realmente asumen el voto de pobreza en sus carnes. La negativa a toda plataforma institucional como vehículo de transformación social casa mal con la relectura de San Pablo, el fundador de la Iglesia católica y los modelos que han pasado a la historia y que éstos pensadores de hoy recogen no han sido precisamente inoperantes e ineficaces. Desde luego no se puede pedir al pensador postmoderno que genere aquello que condena, esto es, plataformas políticas modernas, pero las plataformas alternativas brillan por su ausencia y la presencia de su ausencia se nota demasiado como para que lo imposible nos consuele y se logre atisbar la playa bajo los adoquines. El que la política por-venir nunca llegue acaba amalgamando las prácticas micropolíticas al infinitismo escatológico de la modernidad, a pesar del carpe diem esgrimido por el mesianismo derridiano. De ahí que no ande desencaminado José Luis Pardo al acusar a Giorgio Agamben de un grave defecto moderno, el de incurrir en un formalismo político incapaz de concreción y encarnación. En relación a la

${ }^{4}$ Gilles Deleuze \& Félix Guattari Mil Mesetas. Capitalismo y esquizofrenia. Pre-Textos. Valencia, 1988. Cap.13: «7.000 a.J.C. Aparato de Captura», pág.475. 
deconstrucción del sujeto hay que pensar que ser sujeto tampoco es algo tan terrible y si se presenta la desubjetivación como modelo de liberación nos encontramos con un proceso de vaciamiento en virtud del cual, rousseaunianamente, se trataría de dejar libre al ángel interior que todo el mundo lleva consigo. Frente a ello la subjetivación moderna resulta un momento irrenunciable como necesidad de poner límites a la bestia interior que, hobbesianamente, todo el mundo llevaría dentro ${ }^{5}$, así como, en contra del nomadismo, de poder ser sedentarios y tener raíces, bien hundidas hasta Grecia, así como identidad, sexual, nacional o simplemente psicológica, política y jurídica.

Cuando Foucault dobla el poder vivir como exigencia del poder matar en las guerras, nos plantea la potencia como algo que aumenta amoralmente pero de lo que se deriva un simultáneo grado moral de eficacia, tanto para el bien como para el mal. Bajo este prisma el gran criminal no sería sino alguien que ha empleado su enorme potencia en una dirección de poder socialmente destructiva y, por tanto, como dice Nietzsche ${ }^{6}$, hay que tenerle respeto; porque como tipo huma-

5 Véase a este respecto mi noticia: Antonio Damasio y Spinoza: la biopolitica y la sabiduria holistica

http://www.rebelion.org/noticia.php?id=36773

6 "El delito se inscribe dentro del concepto de atentado contra el orden social. A un rebelde no se le castiga, se le somete. Un rebelde puede ser un hombre despreciable y digno de compasión; en sí, ninguna rebelión tiene nada de despreciable, por lo que el ser rebelde no rebaja a nadie. Hay cosas, por el contrario, en que las rebeldías honran al individuo, descubridor de un motivo social de combate y despabilador, diríamos, de nuestro sueño. El hecho de que el criminal cometa un atentado contra un particular no quiere decir que su instinto no esté contra todo el orden social; el hecho es meramente sintomático. El concepto castigo debe limitarse a ser un concepto: abatimiento de un rebelde, medidas de seguridad contra los abatidos (prisión o media prisión). Pero los castigos no deben expresar desprecio; un criminal será siempre un hombre, un hombre precisamente de valor. Tampoco debe considerarse la pena como expiación, o como indemnización, cual si hubiera una relación de cambio entre culpa y castigo; la pena no purifica, pues el delito no mancha" (Friedrich Nietzsche Der Wille zur Macht, $\$ 740$ ). Lo que con Lévi-Strauss puede matizarse añadiéndole un cierto relativismo cultural muy en consonancia con la noción de las epistemes foucaultiana o de los paradigmas de Kühn:

«Pero, sobre todo, debemos persuadirnos de que si un observador de una sociedad diferente considerara ciertos usos que nos son propios, se le aparecerían con la misma naturaleza que esa antropofagia que nos parece extraña a la noción de civilización. Pienso en nuestras costumbres judiciales y penitenciarias. Estudiándolas desde afuera, uno se siente tentado a oponer dos tipos de sociedades: las que practican la antropofagia, es decir, que ven en la absorción de ciertos individuos poseedores de fuerzas temibles el único medio de neutralizarlas y aun de aprovecharlas, y las que, como la nuestra, adoptan lo que se podría llamar antropoemia (del griego emeîn, vomitar). 
no alcanzaría el nivel del santo, del héroe y del benefactor individual de la humanidad (el científico, el músico, el poeta, el artista, el ingeniero, el filósofo socrático). Pero el individualismo y el aristocratismo de Foucault le hace ver tan sólo el aspecto negativo de los poderes supra-individuales (fuerza de trabajo colectiva, pueblos, naturaleza, divinidad) debido a que su ontología es una monadología de la potencia singular, según la cual, el poder del Estado es necesariamente visto, tras la resaca estalinista, como anulación del poder individual vampirizado por la administración de la vida por un aparato de captura. Muy al contrario, Marx, tendrá una ontología holística del poder, a partir de lo cual lo público y lo político son vistos como más aún que la suma de las fuerzas individuales ${ }^{7}$, esto es, como elevación cualitativa de la potencia humana.

Ubicadas ante el mismo problema han elegido la solución inversa que consiste en expulsar a esos seres temibles fuera del cuerpo social manteniéndolos temporaria o definitivamente aislados, sin contacto con la humanidad, en establecimientos destinados a ese uso. Esta costumbre inspiraría profundo horror a la mayor parte de las sociedades que llamamos primitivas; nos verían con la misma barbarie que nosotros estaríamos tentados de imputarles en razón de sus costumbres simétricas" (Claude Lévi-Strauss Tristes trópicos. Paidós. Barcelona 1992. Novena parte, capítulo 38, pp.441-442).

7 "Así como la fuerza ofensiva de un escuadrón de caballería o la fuerza defensiva de un regimiento de infantería difiere esencialmente de la suma de fuerzas ofensivas y defensivas que despliega por separado cada jinete o infante, [396] la suma mecánica de fuerzas de obreros aislados difiere esencialmente de la potencia social de fuerzas que se despliega cuando muchos brazos cooperan simultáneamente en la misma operación indivisa, como cuando corresponde, por ejemplo, levantar un peso, hacer girar un manubrio o quitar de en medio un obstáculo. El efecto del trabajo combinado, en tales casos, no podría lograrlo el trabajo de individuos aislados, o sólo podría alcanzarlo en espacios de tiempo mucho más prolongados, o sólo en una escala ínfima. No se trata aquí únicamente de un aumento de la fuerza productiva individual, debido a la cooperación, sino de la creación de una fuerza productiva que en sí y para sí es forzoso que sea una fuerza de masas. Prescindiendo de la nueva potencia de fuerzas que surge de la fusión de muchas fuerzas en una fuerza colectiva, el mero contacto social genera, en la mayor parte de los trabajos productivos, una emulación y una peculiar activación de los espíritus vitales (animal spirits), las cuales acrecientan la capacidad individual de rendimiento de tal modo que una docena de personas, trabajando juntas durante una jornada laboral simultánea de 144 horas, suministran un producto total mucho mayor que 12 trabajadores aislados cada uno de los cuales laborara 12 horas, o que un trabajador que lo hiciera durante 12 días consecutivos. Obedece esto a que el hombre es por [397] naturaleza, si no, como afirma Aristóteles, un animal político, en todo caso un animal social" (Karl Marx El Capital. Libro I. secc.IV. Capítulo XI: La Cooperación. Editorial Siglo XXI, Madrid 1998, págs.396-397).

A este respecto véase mi: «Del materialismo histórico a la ontología hermenéutica», en: http://serbal.pntic.mec.es/-cmunoz11/anomalia.pdf 
El reverso del genocidio es la Edad de Oro, el paraíso en la tierra, estando Foucault condenado en un infierno a puerta cerrada y Marx abierto a una bienaventuranza absoluta. En caso de que Foucault simplemente describa cómo es el poder actual para mejor resistirlo, siguiendo el consejo de Maquiavelo de aprender el camino del infierno para evitarlo, el resultado de su descripción es pesimista, al no vislumbrarse lugares desde donde poder resistir. La conclusión es que o bien vivimos bajo el más atroz de los totalitarismos -lo que entra en paradoja con la misma descripción y la anomalía de la crítica- o bien la descripción foucaultiana es parcial y exagerada, resultante de un pesimismo antropológico. Ya que ni habla de otra cosa que del reverso negativo del poder social ni propone ninguna vía posible para que el anverso positivo sea mayormente efectivo, sino tan sólo, finalmente, un sálvese quien pueda individual.

Al menos Tony Negri alentó a las Brigadas Rojas — para qué seguirlo negando a estas alturas en que ya está libre- siguiendo en ello al Gilles Deleuze de Mil Mesetas: "Siempre hay un palestino, pero también un vasco, un corso, para provocar una desestabilización regional de la seguridad (...). Como si constantemente una línea de fuga, incluso si comienza por un minúsculo arroyo, fluyese entre los segmentos y escapase a su centralización, eludiese su totalización ${ }^{8}$ ". Contra el sistema totalitario más omniabarcante y completo de la historia universal, sólo cabría el terrorismo. La idea de que la violencia antisistema sólo retroalimenta a la violencia del sistema totalitario vigente al darle excusas para la represión no es cierta, porque un sistema totalitario no necesita de excusas para la represión, la acomete de cualquier manera y es su vocación el realizarla.

Pero en Occidente tras los ejemplos como el de la banda Baader-Meinhof se ha llegado a un punto en el que la opción por la lucha armada es inútil e inviable, como ha señalado recientemente Gianni Vattimo: «Tú quieres llevarme del lado donde estoy ya yendo personalmente... un izquierdista minoritario, elitista... Pero no, no se puede ir por ahí, no. Mi problema cuando empecé a ser dipu-

${ }^{8}$ Gilles Deleuze \& Félix Guattari Mil Mesetas. Capitalismo y esquizofrenia. Pre-Textos. Valencia, 1988. Cap.9: "1933: Micropolítica y segmentariedad», pág.220. Véanse a este respecto tres breves artículos sobre el fenómeno del Terrorismo en:

http://www.rebelion.org/noticia.php?id=921

http://www.rebelion.org/spain/040330roy.htm

http://www.rebelion.org/spain/040406roy.htm 
tado europeo por izquierda democrática era ya éste: tengo que terminar mi mandato completo sin perder la fe en la democracia... la democracia que ha de ser verdaderamente social y cultural... A veces la pierdo, claro, pero no tengo ni un ápice más de fe tampoco en ninguna revolución violencia en Occidente... porque no es posible" $"$. La apuesta política contemporánea en los países desarrollados pasa por caminos diferentes de la apuesta política en los países del llamado Tercer Mundo. En Occidente la creación de una Europa que ponga límites a la voluntad de poder de los Estados Unidos de Norteamérica y camine por la vía de su tradición socializante en lugar de la liberal anglosajona, en el resto del planeta, una serie de alianzas frente al nuevo imperialismo y al postmoderno colonialismo de la globalización; recuperación de su lengua y sus costumbres, de sus materias primas mediante la nacionalización, defensa de los sistemas de cooperación y comunidad. Todo eso está muy alejado de la micropolítica y es necesario que se lleguen a forjar plataformas de intervención política para el pensamiento contemporáneo o alianzas entre la postmodernidad y la modernidad contra el enemigo común del Capital y el neoliberalismo.

Hasta aquí los comentarios a la mencionada idea de Foucault del doblamiento del poder vivir como poder matar. Y subsiguientemente al ver el problema como una astucia del dispositivo biopolitico se cae en un antropomorfismo del sistema al atribuirle cualidades humanas, ya que el Capital, la Razón o Dios no pueden ser astutos a menos que esa clase de inteligencia sofística que Homero atribuye ya a Ulises, fecundo en ardides (polimathés) sea más allá de un atributo humano

9 «Diálogo con Vartimo: El destino de Europa». [11- Febrero 2004. Entrevista filosófica y politica] Gianni Vattimo y Teresa Oñate. En: Ética de las verdades hoy. Homenaje a Gianni Vattimom. Madrid, UNED, 2006, pág.62. La no violencia del anarquismo de Gianni Vattimo no le ha impedido vislumbrar que la situación actual «involucra un problema enorme y un problema de fuerza. Por ejemplo yo como diputado europeo -y en realidad todo europeo consciente y democrático debería preguntárselo- ¿Qué hago? ¿Tengo que apoyar un ejército europeo o no? Y yo que soy un defensor de la antiviolencia, de la debilitación de la violencia en todos los órdenes... imagínate el dilema ¿Dejamos paso libre a los Estados Unidos y a la globalización del capital multinacional? La extrema izquierda italiana dice sin más que no. Pero realistamente hablando yo no tengo más remedio que apostar por la articulación y el desarrollo de un ejército europeo independiente de la OTAN y de los Estados Unidos, porque siempre voy a estar frente a la amenaza militar de los Estados Unidos... Son problemas concretos de decisión realista coherentes con una posición independiente de los Estados Unidos y no filo-americana” (Ibid.pág.63-64). Véase también otra "Entrevista a Gianni Vattimo" en: 
proyectado supraindividualmente, una propiedad compartida con los dioses. La tesis que defendemos contra Arendt-Foucault y contra Agamben reside específicamente en la focalización del problema, en la reproblematización de lo indicado por ellos y por Marco Díaz Marsá de la siguiente manera: ni politización de la vida (Foucault) ni animalización de la política (Arendt) sino afirmación de la existencia (Nietzsche mediado por Deleuze, Heidegger y Sloterdijk) y política que parta de la Revolución francesa (Kant) y se dirija al socialismo (Marx). Con todo de lo que se trata entonces es de cotejar programas políticos y dirimir cual resulta viable, posible, deseable y articulable.

La búsqueda de la diferencia específica de la sociedad moderna y la recuperación de una relación esencial entre teoría y praxis, van como señala acertadamente Díaz Marsá, juntas en el programa de reproblematización. Sin embargo el deseo de verdad como primado de la praxis sólo ha podido ser tal cuando se reduce la verdad a voluntad de poder y se arranca su tradición de la tradición contemplativa. Con ello se aprecia no sólo una especificidad moderna sino una recurrencia de la historia, la que separa a Platón y Cicerón, a Grecia de Roma, a Maquiavelo frente a Ficción. Conviene tener en cuenta entonces si acaso no incidirá en ese basculamiento un cambio o aceleración de la temporalidad. Si el marxismo acabó otorgando un primado a la producción, reivindicando de ese modo la servidumbre del trabajo como liberación del proletariado, no obstante, el propio Marx señaló muy abundantemente la necesidad de oponer el ocio contemplativo de la teoría y la Grecia clásica al nec-otium, al negocio ${ }^{10}$.

Resulta paradójico que en el mundo moderno la máxima individuación del atomismo liberal se corresponda y coexista con la máxima desindividuación de la sociedad de masas. Tal hibridación indeseable de lo individual-colectivo en expresiones dobles de un bipolarismo superado virtualmente hace que el homo faber y el homo laborans se tornen indistintos ante las estructuras en las que no representan más que una pieza mecánica más, un periférico. Un análisis como el antecedente no se libra de tener que recoger la acusación de Hannah Arendt a los vitalismos, incluido el racio-vitalismo de Ortega, como filosofía totalitaria del fascismo. De modo que retorna al interés del pensamiento contemporáneo

${ }^{10}$ He tratado con detalle este problema en : «La sociedad capitalista como negación del ocio: historia de una paradoja actual». Revista de Filosofía Logos: Razón, Estado y Ciudadanía. Universidad Complutense de Madrid. Vol.35, 2002, pp.193-222. 
la polémica entre bumanismo y antihumanismo que jalonó la historia del estructuralismo y enfrento entre otros muchos a los marxistas althusserianos con los marxistas humanistas, a Heidegger y Lévi-Strauss con Sartre o a Chomsky con Foucault, lo que implica también a las articulaciones de un posthumanismo que se están elaborando en la actualidad. Denunciar el totalitarismo del vitalismo como germen de la biopolítica al tiempo que se quiere recuperar un humanismo de raigambre kantiana a partir de la operación de división entre el reino animal y el reino de lo humano, lo que a nuestro juicio procura realizar Díaz Marsá; constituye un programa teórico en el que antihumanistas declarados, como Heidegger y Foucault, quedan obligados a hablar en kantiano y a servir de fundamento para declinar lo que desde ellos habría de ser indeclinable. El programa de investigación de la libertad que radica lo humano como lugar de preferencia ante la muerte de Dios y el desencantamiento del mundo se convierten en centro de un loable trabajo cuyo defecto consiste en filtrar anacrónicamente por el tamiz kantiano lo que han propuesto pensadores posteriores ${ }^{11}$.

Pretender que lo humano es más que lo animal no solamente es una seria afrenta para la Naturaleza -para evitarlo Deleuze proponía devenir-animal con la mascota antes que constituir Edipo con ella convirtiéndola en miembro de la familia- sino una desatención de la ciencia etológica que lleva tiempo verificando la existencia de cultura animal y, según se mire, quizás también de política animal. Se puede declinar en contrario la bipolaridad hombre / animal indicando que la crueldad, el genocidio y la mentira son ámbitos humanos, mientras que la inocencia, el sano instinto y la noble acción son los atributos del animal. Para que no se abandonase a los perros domésticos en las gasolineras en verano se hacían carteles donde aparecía un perro en medio de una carretera con el lema: "el nunca lo haría" y a riesgo de vulgarizar el nivel de reflexión, pero con fines más catárticos que trivializadores, no cedemos a la tentación de recordar también el aserto: «cuanto más conozco a la gente más me gusta mi perro».

${ }^{11}$ Imposible más que apuntarlo. Véase: Félix Duque ¿Hacia la paz perpetua o hacia el terrorismo perpetuo?.. Madrid, Ediciones Pensamiento, Círculo de Bellas Artes, 2006. Y por nuestra parte: "De la guerra ilegal a la guerra perpetua», en:

http://www.rebelion.org/spain/030722sroyo.htm 


\section{SEGUNDA PARTE: Acerca del término República en Aristóteles. Comentario del libro IV, cap. IX, 1294b de su «Politiká»}

Cuando Aristóteles dice aquello del zoón politikón, traducido unas veces por animal social, otras por animal cívico, otras por animal político, los modernos hemos leído que lo dignificado por lo político era el hombre en tanto ser intermedio entre la esfera de los animales y la de los dioses. ¿Y si fuese al revés? ¿Y si fuese diferente la comprensión que debemos ejercitar sobre Grecia? ¿Y si Aristóteles lo que dignificase con aquella expresión fuese lo político que quedase honrado por su pertenencia a lo animal-natural (physis) y no opuesto a lo divino? ¿Y si fuese incluso más difícil comprender el zoón que lo que lo es ya la ta politiká? La perspectiva entonces cambiaría totalmente y la nueva lectura nos impediría convertir a Aristóteles en humanista, sencillamente, porque en Grecia no se conocía el humanismo. Y eso por mucho que los sofistas y Sócrates tomasen como centro de reflexión los asuntos de la pólis y se haya divulgado en exceso la tesis convencional de la homomesura de Protágoras de Abdera, que Heidegger interpreta de muy otro modo que la tradición metafísica. Si hemos de creer que Platón es fiel al menos en el Protágoras al transmitir el mito de la creación de las ciudades por parte de los hombres, el mito refiere que lo racional (el lógos) es común a hombres y dioses sin pertenecer a ninguno de ellos, que las técnicas proceden de los dioses Hefesto y Atenea, el fuego del titán Prometeo, las capacidades animales de su hermano Epimeteo y el sentimiento moral (aidós) y la justicia (diké) del propio Zeus, que considerará como cualidades propias de la virtud política (areté politiké).

No puede por tanto a nuestro juicio leerse la Politica de Aristóteles como si fuese un tratado kantiano de promoción de la clase media en un incipiente mundo burgués, aunque ciertamente esa es la forma como ha llegado a ser inteligible para nosotros. Cuando Aristóteles habla de "naturaleza política del hombre" no está hablando de zoé ni de bios, sino que está hablando de physis. Al menos tal sería una posible interpretación que siguiendo el Andenken heideggeriano modificaría por completo la estructura de la reproblematización que nos ofrece Díaz Marsá y nos obliga a reproblematizar la reproblematización misma, preguntándonos por sus presupuestos.

El título de La República con el que se conoce la principal obra de asunto político de Platón, no corresponde al original griego de Politeia. La traducción correcta sería «Sobre el Estado» o «Del régimen de gobierno de la ciudad-estado 
(polis)» o «De las formas de gobierno». Pero a partir de la traducción latina como Res publica, empleado por Cicerón en su tratado sobre el mismo tema, vino a dar en La República en castellano. Lo que es indiscutible es que los escritores políticos de la Grecia clásica fueron los inventores del vocablo «república» y quienes forjaron y dejaron bien implantados los principios de la filosofía política en una serie de libros de los que aún algunos conservamos.

Puesto que se trata en tales libros de los primeros textos completos que tenemos sobre lo que hoy se denomina ciencia política y existe una determinada forma de gobierno y un tipo de organización política, entre otros, al que llamamos "República»; las traducciones tradicionales son totalmente inadecuadas. Mejor título para las obras de Platón y Aristóteles pensamos que sería el primero que apuntamos, esto es, «Sobre el Estado», que apunta completamente a la esencia de la investigación política, que no es otra que el análisis de las formas de gobierno y de convivencia, y remite al lector hacia la certera idea de que se encuentra frente a verdaderos tratados de ciencia política.

La obra platónica que mencionamos al principio lleva por subtítulo peri dikaiou, quedando su título completo como sigue: «Del Estado o sobre la justicia". Teniendo presente lo antedicho, hay no obstante que señalar, que el título por el que se conocen estas obras está tan arraigado y resulta tan difícil conseguir su sustitución, que pensamos que lo más adecuado es hacer como la mayoría de los especialistas: dejar clara la incorrección y mantener sin embargo al mencionarlas, los títulos tradicionales de las mismas.

La obra que conocemos como La Política de Aristóteles no ha seguido mejor suerte, ya que teniendo por título Politiká, lo que indica, simplemente, «libros de tema político" o «sobre las cosas relativas a la polis», también fue vertida al latín como Res publica, dándosele en castellano el título que conocemos; (inadecuación que se repite en su obra Politeia athenaion, vertida al castellano como «República de los atenienses o Constitución de los atenienses» cuando se habría de entitular como: “Del Estado ateniense»). Pero en Aristóteles se añade una complicación más al emplear éste la palabra politeia para designar una determinada forma de gobierno además de para designar los regímenes de gobierno en general. Aristóteles fue el inventor de la idea de un régimen concreto, el republicano, formado por la mezcla de la democracia y la oligarquía o por la coexistencia de elementos democráticos y elementos oligárquicos en equilibrio recí- 
proco, aunque predominando los primeros sobre los segundos, si bien en Ética a Nicómaco (1160b) habla de que algunos lo identifican con la timocracia, teniéndolo por un régimen basado en la propiedad.

No hay que entender las expresiones "pueblo» o «voluntad popular» al modo irracionalista del nacionalsocialismo, como Leni Riefenstahl en "El triunfo de la voluntad", no hay que entender esos conceptos como la voluntad nazificada a partir de Schopenhauer o Spengler; sino al modo de Rousseau, como "voluntad general" como una "razón común" (que diría García Calvo). Pero hoy en día hablar públicamente de "pueblo" o "voluntad popular" implica ser inmediatamente descalificado como presentador de argumentos de pretensiones totalitarias, ejercicio realizado por un liberalismo economicista ante el cual todo lo que no sea él mismo es tachado de totalitarismo.

Pero lo que significa "pueblo" en la tradición comunista (no en la nacionalsocialista ni en la totalitarista) consiste en el a priori de la presuposición de que los demás son tan racionales e irracionales como nosotros mismos y pueden pretender fundar un Estado (o tomar decisiones sobre el propio Estado), tal y como lo pretendieron y lograron los judíos no hace mucho y lo intentan los palestinos, los kurdos y los vascos, hoy en día, entre otros.

El término primitivo u originario, si bien complejo, para que se pueda llegar a hablar de Estado es el de "sociedad política", lo que nos remite ya a un compuesto: a una "sociedad" y una "política", es decir, una "comunidad" y una "ciudad-estado", a cuya pertenencia aludiría Aristóteles al decir que el hombre es un "animal político», configuración o agrupación humana que comenzará denominándosela, en griego politeia, y traduciéndola al latín, "república" (res-publica). Y es que el término aristotélico zôon politikón (Politica, 1253a) puede perfectamente traducirse tanto por «animal social», como por "animal cívico» (podría traducirse igualmente por "animal político") señalándose con ello, además de la posible indistinción entre animal y hombre, naturaleza y cultura, comunidad y polis, precisamente, el tema del nacimiento de nuestra forma de concebir la política en Grecia; ya que en griego, hay que distinguir entre varios elementos que conformaron la polis:

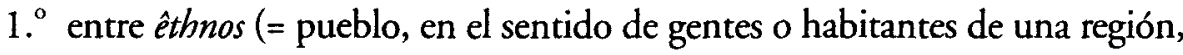
de donde procede la palabra etnología) y kômê ( $=$ aldea, pueblo, en el sentido de lugar o continente del êthnos antes mencionado). 
2. ${ }^{\circ}$ entre leôs (= pueblo en el sentido de las huestes -ôi leois- de las que, como de un personaje más, hablan los escritos homericos en la "Ilíada", término próximo al «Volk» alemán del romanticismo, pero que luego devendrá en los ordenados «hoplitas») y dêmos (= pueblo, políticamente organizado, en subgrupos de la polis, como si fuesen partidos políticos), y

3. finalmente, entre pólis (= ciudad, no sólo el casco urbano -por ejemplo, la villa de Madrid - sino toda la región — por ejemplo, la Comunidad de Madrid - formada por numerosos dêmos o dividida en lo que originariamente fueron familias y luego pasaron a ser circunscripciones electorales, incluyendo el campo y la ciudad) y assty (= aldea, centro de la tribu, originariamente sinónimo de kômê, pero que luego, más adelante, vino a querer decir "ciudad», en el sentido de centro urbano, villa - como la villa de Madrid en el ejemplo anterior y cuyo centro, a su vez, era el ágora).

Aristóteles dice que "cualquier ciudad (pólis) es una cierta comunidad (koinonía)» (1252a) pero después empieza a realizar distinciones entre los tipos de comunidad: «la familia (la casa, oikós) es la comunidad (koinonía), constituida por naturaleza (physis) para satisfacción de lo cotidiano", pero, "por otra parte, la comunidad primaria compuesta de casas no exclusivamente para la satisfacción de lo cotidiano es la aldea (kômê)", mientras que, «la ciudad-estado (pólis) es la comunidad, procedente de varias aldeas (kômê)" (Política, 1252b, edición de Ross). La ciudad es lo común tanto en el sentido de lo bueno y lo malo (costumbre, A), como de lo justo y lo injusto (razón, B), y eso es lo que funda tanto la comunidad humana (A) como la ciudad (B), que o bien son simultáneas o bien se superpone la segunda a la primera, no necesariamente borrándola.

En el Protágoras de Platón, Sócrates, comenzará dudando que exista una ciencia política y terminará pensando que es posible que sí la haya, a la inversa del sofista que da nombre al diálogo; luego, en la República, Platón creerá haberla encontrado y hallarse en posesión de ella, para después, volver a ponerlo en duda, pues, en El Político, seguramente tras sus propios fracasos en Siracusa, no hay ya ciencia política sino, a lo sumo, un arte de la misma semejante al de tejer, pues la redacción del último diálogo mencionado es posible que se sitúe después del segundo y antes del tercero de los viajes que Platón realizó a Sicilia, entre los años 366 y 362 a.C., si es que no más tarde. 
El Político es la continuación del Sofista, pues se trata de una especie de trilogía en la que primero se expondría la definición de sofista, después la del politico y por último la del filósofo. No nos ha llegado ningún diálogo sobre el filósofo, luego es plausible que Platón no se ocupase ya nunca de corregir la visión del mismo que se nos presenta en la República, y que, por tanto, el filósofo-rey quedara como la idea de gobernante perfecto del Estado ideal. Pues la metáfora del político como "pastor del rebaño humano" es ahora descartada, por haber estado hablándose con ella "de un dios en lugar de un mortal" (Político 275a).

«El Político reafirma la distinción de la República entre una política ideal única y todas las demás, pero, mientras que la República se concentra en la ideal, pensara o no Platón que pudiera llegar a realizarse alguna vez, el Político reconoce que ella no es de este mundo. Nuestros mejores políticos son sólo humanos y el objetivo presente es, sin perder de vista «la única constitución verdadera" como norma y guía, planear una sociedad tal y como lo permiten las imperfecciones humanas ${ }^{12}$ ".

Este punto final de Platón será el punto de partida de Aristóteles. El libro IV de la Política aristotélica comienza, en su capítulo primero, hablando de una ciencia (episteme) a la que correspondería el análisis de cuál habría de ser el mejor sistema político (1288b10), se nos dice, al igual que al comienzo del Tratado Politico de Spinoza (I, 1-3) que se acierta más en la teoría política que en su aplicación práctica (1289 a), con lo cual se estará hablando de un acierto teórico deductivo más que de un acierto pragmático implantado socialmente. El capítulo II expone ya los sistemas divididos en dos tríadas de tres correctos (que no perfectos), monarquía, aristocracia y república, y tres desviaciones de éstos «la tiranía de la monarquía, la oligarquía de la aristocracia y la democracia de la república». Sobre la aristocracia y la monarquía ya se ha tratado con anterioridad, quedan por tratar los demás, pero a continuación, se va a dedicar el comentario a la democracia, la oligarquía y la república. Pero antes se nos dice que la forma «más moderada es la democracia» (1289b) y se alude en ése momento a Platón (remitiéndosenos a Político 302e-303a) cuando juzgaba que si todos los sistemas son buenos

12 Guthrie, W.K.C. Historia de la Filosofia Griega. Vol.V: «Platón: segunda época y la Academia». II. "Parménides, Teeteto, Sofista, Político». 4. "El Político. Teoría política»: a) El Político y la República, p.198. Editorial Gredos. Madrid 1992. [Primera edición inglesa. Cambridge University Press 1978]. 
el peor es la democracia y si malos, el mejor. Y puede decirse que Aristóteles se inclinaría por la última posición, ya que a continuación se nos dice que la oligarquía no es mejor que otro régimen sino menos mala y sólo así encajaría su doctrina ético-política del justo medio en el problema que nos ocupa. El régimen ideal es una entelequia teorética que no es enteramente aplicable en la práctica, los regímenes correctos son en ese sentido también tipos ideales, quedando para la realidad las desviaciones de los tipos ideales, los que entrañan corrupción y no pueden alcanzar la pureza prístina de lo absoluto. En el capitulo III se lleva a cabo un análisis teorético de las partes de los sistemas políticos y se nos explica que en general, ya en el terreno empírico-práctico "parece que hay dos, e igual que en el caso de los vientos se habla de los vientos del Norte y del Sur, en tanto que los demás son desviaciones de éstos, así también entre los sistemas hay dos, democracia y oligarquía, pues la aristocracia se considera una especie de la oligarquía, ya que es la oligarquía en cierto modo, y la llamada república una especie de democracia, como entre los vientos" (1290 a). Los regímenes existentes en la práctica son principalmente y en general, los que surgen de dos tipos de desviaciones, la desviación de la aristocracia (oligarquía) y la desviación de la república (democracia).

El capítulo IV se dedica a la democracia, donde viene la definición siguiente: "tendremos democracia cuando los libres y pobres, siendo muchos, tengan el control del poder" (1290b), pero hay que fijarse en que un poco antes se nos ha dicho: "varios son los elementos de la democracia y de la oligarquía" (Ibid). Un elemento esencial, por tanto, sin el cual no se podrá hablar de que haya democracia es el de que los muchos tengan el control del poder. Tras hablársenos a continuación de la guerra externa e interna, se nos dice que: "es indispensable que algunos ciudadanos participen de la virtud de los políticos» (1291b), ahí tenemos a la actividad política caracterizada como virtud, la areté politiké, o capacidad para el gobierno; que ha de estar repartida entre los ciudadanos de tal modo que hasta se pueda en ocasiones acudir a la designación de los cargos por sorteo, puesto que todos estarán capacitados. De los dos vientos principales, democracia y oligarquía, salen los dos partidos o facciones principales, pobres y ricos, pero no hay que olvidar que en la práctica «hay diversas formas de democracia y de oligarquía" (1291b); y al exponer las clases sociales de entre los ciudadanos que se dedican a tareas productivas (que no esclavos) se nos habla de campesinos, artesanos, comerciantes y, por último, la de la clase de los jornaleros: «la que cuenta con tan poca renta que no se puede permitir el descanso, los que sin ser 
de ambos padres ciudadanos son libres» (Ibid). Después se nos dice que «la principal forma de democracia es la que se funda sobretodo en la igualdad" (Ibid). Elemento esencial el de la igualdad, que en su forma económica, se puede destacar a partir de Aristóteles, aunque él no se detenga demasiado en ello, seguramente porque ya lo habría hecho en su tratado Perí oikonomías, que se nos ha perdido. "Una forma de democracia es ésta, y otra que se establezcan las magistraturas a partir de las rentas, siendo éstas pequeñas", ya que si son grandes no sería democracia sino oligarquía o timocracia. La democracia que parece preferible para Aristóteles es la que "participan todos pero gobierna la ley" (1292 a) porque respecto a la demagogia se nos dice que "tal democracia se corresponde con la tiranía (...) pues donde no gobiernan las leyes no hay sistema". De aquí cabe suponer que donde gobierna un tirano, un demagogo, que una teocracia, por ejemplo, no sería en cuanto forma considerada como un sistema político, y al límite que sólo lo sería el democrático. El capítulo $\mathrm{V}$ comienza declarando que en la oligarquía "las magistraturas dependen de rentas». El sexto vuelve sobre la dicotomía general democracia / oligarquía para declarar que no hay tipos puros pero sí predominio de un sector. La renta es un elemento esencial para la participación política, cosa que se puede combinar con el trabajo de hombre libre, pero para la que hace falta ocio. Es un rasgo oligárquico de una democracia cuando "la posibilidad de participar no existe por falta de recursos", se examinan dos más y se llega a la cuarta: «Una cuarta forma de democracia es la que cronológicamente ha surgido en último lugar en las ciudades, pues al haberse hecho mucho mayores las ciudades que las del comienzo y contar con gran cantidad de recursos, todos (los ciudadanos libres) participan en el gobierno, por la superioridad de la multitud, e incluso intervienen y gobiernan los pobres, porque pueden tener tiempo libre gracias a que reciben una paga» (1293 a). Tipo de democracia que interesa destacar, la contemporánea de Aristóteles y de la que éste se desmarca un tanto al decir que no se da en ella el gobierno de las leyes sino el gobierno de los pobres. Pero eso lo dice porque pasa a hablar del justo medio que se daría en la oligarquía ideal en la que nadie sería rico ni pobre, primer tipo de oligarquía del que se van exponiendo sus desviaciones. En el capítulo VII se nos habla de la existencia de una forma política «que se denomina con el nombre común a todos (pues lo llaman politeia)», régimen del que se habría olvidado Platón (1293b).

Y el capítulo VIII y IX, se dedican a examinar ese régimen infrecuente que se denomina con el nombre común a todos. Al comienzo del VIII se nos dice: "Es la república, sencillamente, una mezcla de oligarquía y democracia. Suele dar- 
se el nombre de repúblicas a los regímenes que se inclinan hacia la democracia, y a los que más bien se inclinan hacia la oligarquía, aristocracias, porque la educación y la nobleza van unidas a los más ricos». "Tres son los elementos que se disputan la igualdad del sistema político: libertad, dinero (renta) y virtud; el cuarto es la nobleza» (1294 a). El capitulo IX abunda en las características del régimen republicano en general, que será un termino medio (doctrina del justo medio) entre oligarquía y democracia, existiendo tres formas con los elementos oligárquico-democráticos a partir de los que se constituye la síntesis. 10) Respecto al gobierno ciudadano, se nos pone el ejemplo concreto de la administración de justicia: el elemento oligárquico fija para los ricos una multa por no participar y a los pobres ningún salario; el elemento democrático consiste en que haya "para los pobres un salario por participar y para los ricos, ninguna multa por no participar», siendo la república la mezcla de ambas. $\left.2^{\circ}\right)$ Se trata ahora de la república no sólo como mezcla sino como justo medio (término medio): que se pueda asistir a la Asamblea ni con una renta elevada ni sin renta, sino con una renta intermedia. $3^{\circ}$ ) Entre los elementos democráticos está la atribución de los cargos por sorteo y sin depender de la renta, entre los oligárquicos por elección y dependiendo de la renta. Lo intermedio ahora será por elección y sin depender de la renta, en la república. Aristóteles no nos dice lo que él prefiere sino que expone elementos democráticos frente a elementos oligárquicos y su amalgama en el régimen republicano. Ahora viene el ejemplo concreto de los Lacedemonios, como sistema mixto, esto es, republicano, en el que se pueden observar juntos elementos de cada sistema general de gobierno, y tras mencionar ese ejemplo concreto, caso particular en una exposición general, se nos indica (acerca del régimen lacedemonio): «Muchos intentan hablar de él como si se tratara de una democracia, por tener muchos elementos democráticos en su estructuran, como, por ejemplo: «igual (...) educación, (...) alimentación, (...) y vestido" (1294b). No se está hablando del régimen lacedemonio, se está poniendo el ejemplo concreto del régimen lacedemonio para ver en él tres elementos esenciales de la democracia o más bien tres elementos estructurales de un sistema político específicamente democráticos; la igual educación, alimentación y vestido, incrustados en su estructura de forma que, en combinación y mezcla sintética con los aspectos oligárquicos, hagan del régimen lacedemonio un ejemplo particular de aquél régimen general que se viene llamando república y del que se viene hablando desde atrás y discriminando, en todo momento, de manera teorética pero aduciendo ejemplos empíricos concretos, entre los elementos que esencialmente pertenecen a la forma democracia y los que pertenecen a la forma oligarquía, pues 
como se vio y ya cité con anterioridad: "parece que hay dos, e igual que en el caso de los vientos se habla de los vientos del Norte y del Sur, en tanto que los demás son desviaciones de éstos, así también entre los sistemas hay dos, democracia y oligarquía, pues la aristocracia se considera una especie de la oligarquía, ya que es la oligarquía en cierto modo, y la llamada república una especie de democracia» (1290 a).

En la actualidad, desde la lectura intempestiva de los clásicos griegos, matriz originaria de nuestra cultura política, el trasfondo multicultural de la polis griega se escapa, junto a la consideración del capiralismo como nuevo Imperio macedónico, a la reflexión reproblematizadora del presente. De ahí que la tematización de la política contemporánea tenga que abarcar conjuntamente el hecho de que pertenezcamos a la sociedad de mercancías con el hecho de que habitemos un mundo con identidades, si es que queremos aportar alguna comprensión encaminada a recuperar el privilegio de la acción, esencia de la vida pública.

\section{TERCERA PARTE: De la síntesis disyuntiva entre la ley pública y la libertad privada como tarea de una izquierda postmoderna}

Evitar mencionar la palabra Capital por temor a la censura que se cierne sobre la crítica realizada desde el sistema bajo el que se habita está volviendo ciega y tuerta a la filosofía crítica. Esmerada en recursos metafóricos e irónicos para esquivar la sutil represión del neoliberalismo vigente y triunfante contra todo aquel que no comulga fielmente con sus principios la filosofía contemporánea adolece de una gran ambigüedad y huye del compromiso que llevó a Jean-Paul Sartre, padre indiscutible de todo el pensamiento francés contemporáneo, a rechazar el Premio Nobel de Literatura y a indicar, todavía en 1965: «No creo que el socialismo exista hoy en parte alguna. Creo que hay países más adelantados que otros, porque han socializado sus medios de producción" (Jean-Paul Sartre, en: "Entrevista a Jean-Paul Sartre ${ }^{13}$ ". Apremiados para la historia narrada por los vencidos el modelo socialista es inmediatamente amalgamado con el totalitarismo y descartado como propuesta política para el por-venir en los pensadores de la post-

${ }^{13}$ "Entrevista a Jean-Paul Sartre». Paris, octubre-noviembre de 1965, por Jorge Semprún. Cuadernos del Ruedo Ibérico, n. ${ }^{\circ}$ 3. Accesible en:

http://www.filosofia.org/hem/dep/cri/ri03078.htm 
modernidad, mientras en el devenir real de los pueblos de Latinoamérica y Asia se renueva el legado del marxismo y se vuelve a intentar la aventura de la libertad a través de la garantía de la igualdad.

El capitalismo requiere una renovación incesante de mercancías y una revolución imparable de la tecnología enfocada a tal fin. Por eso, el sistema de mercado, bajo la fachada de un mundo en perpetuo cambio, lo que constituye un mundo en perfecta repetición de lo mismo, en idéntica reproducción de mercancías. La verdadera creatividad está ausente de la producción en serie, ya que cualquier determinación que se le pone a la creatividad, la violenta, la fuerza, la tuerce y la convierte en sierva cuando para ser tal debe permanecer libre y soberana. Ese fin que justifica la transformación de los medios de producción en medios de una destrucción incesante de lo mismo es la producción de un plusvalor acumulable piramidalmente desde su máxima concentración en el pequeño vértice superior hasta su plena ausencia en la extensa base. Para el monoteísmo del mercado que quisiera instaurar el valor de cambio como único valor, el arte no es sino una mercancía más en un mundo en el que, como decía Marx, un palacio equivale a unos cuantos millones de latas de betún. Las vanguardias fueron absorbidas a causa de ello por el mercado y convertidas en artículo de comercio, tasadas al precio de la oferta y la demanda, el dinero por el que se cotizan representa su reducción al estado de espectralidad. Pero la reducción a fantasma de todo lo corpóreo y a espectro de todo lo concreto, si bien es un ideal proyectivo del capitalismo, resulta algo imposible; ya que subsisten siempre elementos inalienables que se resisten a semejante trato y sobre los que, no siendo susceptibles de compra-venta, lo que procura realizar la lógica del mercado es declarar su inexistencia y ocultarlos bajo un tupido velo.

No obstante la importante salvedad antepuesta a la idea de un tiempo de la venalidad universal, resulta bajo el prisma de la venalidad evidente, que en la actualidad, el arte y el pensamiento que se dicen libres se encuentran más esclavos que nunca. Una mirada a los museos contemporáneos o un vistazo a los bestsellers de la filosofía, demuestra, rápidamente, si la ojeada es lo suficientemente crítica; que la dependencia del Mercado constriñe la actividad estética e intelectual, dirigiéndola por cauces específicos y prediseñando su producción antes incluso de consentir su gestación. El monopolio de la educación por un enfoque pragmático encaminado a "ganarse la vida" dirige ya desde la infancia hasta la adolescencia la formación de no pocas mentes hacia las actividades mercantil- 
mente relevantes. Después, entre los anómalos que hayan superado ese primer constreñimiento y represión, la sistemática formación posterior los lleva a uno de tres destinos posibles: a) $O$ bien se refugian en un círculo vicioso interior: especialidades cultivadas por círculos reducidos y autorreferenciales que producen lo que consumen. b) $\mathrm{O}$ bien se forman y consagran a la producción de nuevos formadores en un círculo vicioso exterior. c) $\mathrm{O}$ bien se acaban encontrando con el exterior $y$, entonces, permanecen subsistiendo en los márgenes o se han de vender como fuerza de trabajo artístico e intelectual a las necesidades del sistema de mercado.

La famosa supuesta formación plural de la sociedad capitalista no conoce el librepensamiento, no consiente la verdadera crítica de lo establecido y no admite las dinámicas ideológicas que no puedan encasillarse y clasificarse en determinados grupos de presión.

Toda la formación primaria y secundaria que llevan a cabo principalmente las baterías de imágenes emitidas por los mass media en incesante bombardeo sobredeterminan el legado tendencioso administrado por la escuela y terminan calcificando las mentes en una de las múltiples opciones de lo mismo que conocemos en la ideología actual como pluralidad de formas de vida de las sociedades abiertas, que, en realidad, a lo que responden es a una sola forma de vida efectiva, la del homo oikonomicus u hombre mercancía. Bajo la sobreestructura ideológica de máscara plural subyace un modelo económico único para un pensamiento único, un monismo que se bifurca en dos opciones políticas, las cuales, al alternarse, generan la ilusión de movimiento y cambio.

A la opción liberal-capitalista se opone la opción social-capitalista, sin que haya ninguna posibilidad de que las demás opciones políticas (también capitalistas) lleguen a tener un papel decisivo en materia de economía y policía, lo realmente importante; sino tan sólo un rol de pacto en relación a la intervención en aquellos lugares en los que no se debería intervenir, esto es, en el terreno de las costumbres, y otro rol de reparto de la tajada capitalista que el sector privado cree con todo derecho que le debe el sector público. Cualquier formación politica que ponga en cuestión de manera efectiva la economía capitalista es inmediatamente declarada ilegal y terrorista, consintiéndose las formaciones políticas que ponen en cuestión el sistema vigente de palabra pero no de obra, ya que, ponerlo en cuestión de obra se considera «antidemocrático» (esto es sinónimo 
de anticapitalista para el pensamiento único) y, por tanto, necesitado de «democratización» (esto es, bombardeos masivos).

El arte y el pensamiento que más aparecen en los medios de comunicación no escapan a la lógica del capitalismo sino que siguen el mismo destino que la economía de mercado ha reservado para la política ( $y$, en realidad, para todas las actividades humanas en general) la de ser su sierva, su esclava, su lacaya y su zalamera pretendiente.

Con todo, del diagnóstico de un cierre de toda virtualidad revolucionaria en el plano macropolítico de Occidente no debe derivarse el derrotismo y la desesperanza. El diagnóstico del "todo esta perdido", manifiesto ya en la tesis marxista del paso de la subsunción formal a la subsunción real; esa orwelliana y houxleiana aporía a la que llegó Marx en el Capítulo VI inédito de El Capital, según la cual, el capitalismo habría rebasado el plano de la constitución de las mercancías y ya sería capaz de la producción de subjetividades, no puede derivarse la actitud derrotista, nihilista, cínica y de transfugismo a la derecha que ha asolado a la izquierda. La deriva es explicable pero no digna de ser compartida. Dentro del pensamiento contemporáneo Foucault se encargaría de decretar el cierre de todo escape al sistema y la omnipresencia del poder a todos los niveles de la realidad en obras como Vigilar y castigar, diagnosticando que se había pasado ya a sociedad disciplinaria estigmatizante de toda anomalía como enfermedad y normalizadora en analogía con la medicina, por lo que no valdrían ya las propuestas de emancipación clásicas para implementar la revolución sino, a lo sumo, la nostalgia por un afuera del poder. Promovería por tanto un modo de resistencia individual basado en el placer epicúreo y en el cuidado de sí, lejos de cualquier resistencia organizada. Deleuze se ocuparía, por su parte, de señalar que la sociedad disciplinaria es al tiempo una sociedad de control, promoviendo la micropolítica de subgrupúsculos como únicos lugares desde los que presentar batalla en una guerra de guerrillas entre las manadas nómadas y una gigantesca Maquina de Guerra. Y por su parte Lyotard decretaría que todos los planteamientos teóricos que habían presupuesto una línea histórica que rebasar entre la barbarie y el socialismo estaban infectados de un principio literario de origen judeocristiano que soñaba con el círculo perfecto de un sujeto de la Historia consistente en la trayectoria desde la salida del paraíso hasta su regreso al mismo. Proponiendo por ello abandonar toda propuesta de envergadura universal en el tiempo histórico y a favor de la implementación de narraciones híbridas y fragmentarias, más locales que generalizantes, más estéticas que políticas. 
El giro estético de la hermenéutica postmoderna y del postestructuralismo francés no está del todo desencaminado y conviene retener sus logros al desechar sus desaciertos. Como desacierto hemos señalado su configuración como un neoanarquismo egotista, transido de individualidad existencial pero carente de vinculación comunitaria. Así, tanto el pensamiento de la biopolítica de Giorgio Agamben como el marxismo sin Estado favorable a la Autonomía Operaria de Tony Negri o Paolo Virno, pueden convertirse sin demasiadas dificultades en un anarquismo de derechas con tal de violentar la apuesta por la singularidad multitudinaria transformándola en la apuesta liberal por el individualismo del mercado mundializado. Hay un acuerdo entre las izquierdas radicales en el diagnóstico de la sociedad en que vivimos, bajo la máscara de la sociedad del bienestar propuesta por la socialdemocracia y por la sociedad de las oportunidades individuales propuesta por el neoliberalismo estaríamos habitando bajo un Totalitarismo. Tras el totalitarismo nacionalsocialista y el estalinista habríamos pasado a un totalitarismo de la burocracia y el mercado, de la administración de la vida humana hasta sus últimos detalles. La diferencia entre los actuales neomarxismos y la postmodernidad reside en el papel que se le otorga al Estado; siendo aún para los primeros la maquinaria que hay que tomar para que embride a la economía y puedan tomarse decisiones políticas y constituyendo para los segundos una kafkiana forma de opresión indiscernible como tal de la mercantil y no utilizable como herramienta para ninguna finalidad emancipatoria. Así establecida, si bien con muy nuevos vocabularios y una ingente literatura la polémica y dialéctica en el seno de las izquierdas radicales no ofrece casi ninguna novedad respecto a la controversia entre Marx y Bakunin.

Como acierto del pensamiento contemporáneo tendríamos su vinculación al dominio del arte como territorio mucho menos dominable y sometible a los intereses de las voluntades de poder mundanas que el pensamiento sujeto a las directrices de las ciencias positivas. La filosofía edificante estaría libre de absolutismo y comprendería la diversidad, la pluralidad, la complejidad y la necesidad de las vinculaciones y relaciones entre la multiplicidad irreductible del mundo de la vida. Todo lo abstracto en el pensamiento científico-sistemático del formalismo moderno tendrá que devenir concreto so pena de quedarse en simple declaración de buena voluntad tan esgrimida en la teoría como irrealizada en la praxis. El descabalgamiento del humanismo como línea directriz de la modernidad, en lugar de volver a entronizar a Dios, habrá de volverse mundano y, como posthumanismo, reintegrar al hombre en cuanto que es naturaleza en un ecolo- 
gismo que nos devuelva las raíces, arrancadas de cuajo por una ciudadanía virtual. El derecho a conservar entonces la tierra no implica ya un conservadurismo, como se demuestra en el comunitarismo y en el multiculturalismo de raigambre aristotélica; un pensamiento actual opuesto al sistema de la neoderecha hegeliana ansioso de declarar el Fin de la Historia o de fomentar el Choque de Civilizaciones.

Debido a haber esperado demasiado la generación del 68 acometió con denuedo su propia desesperanza, olvidando que antes que ellos, otras generaciones y la de los primeros socialistas y anarquistas en particular, vivieron condiciones de cierre y represión mucho más duras que las actuales. Si bien la flexibilidad del poder no lo hace menos violento a nivel estructural sino, muy al contrario, mucho más férreo; compuesto entonces de una aleación que se dobla, pliega y repliega, recuperando luego su posición original. La metáfora Oriental que llevó a Jigoro Kano a la invención del Judo, la del junco flexible que se dobla ante el huracán y después recupera su forma frente al roble que se rompe, no sólo ha servido de metáfora para la subversión y la guerrilla, sino que más bien ha sido asimilada por un poder que ha resultado tanto más fuerte cuanto más débil aparece y más humanista comparece. De ahí que no podamos confiarnos demasiado en las propuestas de sabotaje de Tony Negri, o las flexibles y rizomáticas de Gilles Deleuze, ni siquiera en el pensamiento débil de Gianni Vattimo, al menos sin darnos cuenta de que esa estrategia de debilitación de las estructuras fuertes no es patrimonio de la izquierda sino que ha sido utilizada y sigue siendo empleada también por el capitalismo. Resulta patente que si un neoliberal lee El Capital con una hermenéutica proclive a poner en funcionamiento todo aquello que Marx condena como explotación habrá obtenido de su mayor oponente las mejores clases en vistas a ser un capitalista salvaje. Luego no sólo importa entonces la forma de presentar oposición, resistencia, pensamiento y estética alternativas, sino que resulta igualmente fundamental tener en cuenta su contenido y la dirección o vector de incidencia sociopolítica. La tesis gramsciana acerca del maquiavelismo, que los príncipes ya sabían muy bien como conducirse para sojuzgar a los pueblos y que el florentino enseñaba a las multitudes como se comportan los príncipes y nada aportaba a los ilustrados poderosos que bien sabían explotar, puede ponerse en entredicho. En nuestro tiempo Leo Strauss, filósofo-político mentor de los neocons de la administración Bush (como Paul Wolfowitz) ha diseñado un Platón acorde con la mentira de Estado y un Maquiavelo proclive a la alta conspiración, mientras politólogos como Pierre François Moreau construyen un Spi- 
noza protosionista y liberal. Y es que tras el derrumbe de la Unión Soviética muchos intelectuales que han cambiado de chaqueta han pretendido llevarse consigo en las alforjas a los pensadores que habían estudiado con denuedo y devoción, atribuyéndoles a ellos los cambios de carácter propios. Llegará el día en el que un famoso intelectual descubra que Marx era neoliberal y a quien realice semejante descubrimiento científico se le cubrirá de oro y se le llenará la boca de micrófonos, la agenda de citas y la cara de focos de luces y cámaras de televisión. Aunque si bien no hay verdad última y definitiva de un texto quizás sí que haya límites a la interpretación.

Podemos entonces a nuestra vez ver en el derrumbe del modelo soviético y en las truncadas esperanzas del sesentayochismo toda la resaca de anti-marxismo y revisionismo de nuestro pasado reciente y diagnosticar a la altura de nuestro tiempo que, siguiendo esa estela de la muerte del arte y de la muerte de la política en un mundo sin fisuras, asfixiándose en un espacio completamente gobernado por gigantescos macropoderes condensados en el capitalismo; muchos intelectuales y artistas o se retiraron del mundanal ruido o se corrompieron definitivamente (y algunos sin moverse del sitio) cuando no se tornaron virulentos reaccionarios llenos de resentimiento hacia lo que creyeron en su juventud y supurando odio de basilisco hacia quienes han continuado en todo aquello que ellos traicionaron.

Lo que no comprenden nuestros mayores en tan trágica historia es que todos esos itinerarios pertenecen tan sólo a la cultura de las nuevas generaciones y no a sus vivencias. En ese sentido resulta poco traumática la caída del bloque comunista o la derrota de la segunda república española para los jóvenes europeos, a menos que se quieran traspasar los traumas ajenos como herencia propia. $Y$ aun en el trasvase la herida se despotencia y se convierte en espectral, dando paso a la reconciliación con lo mejor de la tradición y el abandono de sus errancias. Considerarlo todo errancia desde Platón a Nietzsche como quisiera un cierto Heidegger para quedarse sólo él y los presocráticos en el territorio del pensamiento del ser no es sino otra versión, bajo el nombre de hundimiento en la Historia de la Metafisica, de la teoría marxista de la subsunción real o la neoanarquista de la biopolítica. Dado el triunfo de la ilustración burguesa liberal y del capitalismo consistente en el vaciamiento de todo lo concreto y la desvalorización de todo contenido por medio de un formalismo abstracto que desertifica la tierra entera, entonces, sólo un dios podría salvarnos. 
El gran filósofo español Agustín García Calvo en una de sus célebres conferencias, la impartida en la Facultad de Psicología de la UCM en el ciclo del año 2000 sobre "El papel de la psicología académica " ${ }^{14}$ y luego publicada por escrito hacía notar que las jergas de la Academia impedían la comprensión y el entendimiento de lo que alli se enunciaba y enseñaba; oponiendo al lenguaje científico su propio y recurrente esfuerzo por manifestarse en la mayor cercanía del lenguaje corriente: «Esto, como todo lo que voy a dejarme decir por esta boca, tiene la dificultad de que es demasiado claro. Y ésta es una dificultad evidente, sobre todo estando en la academia, donde el curso normal es, para fingir que se entiende, recurrir a las jergas, reducirlo todo a jergas más o menos científicas, garantizando de esa manera que nada se entienda de verdad. Por mi parte, empleo en todo lo posible el lenguaje corriente». Expuso de ese modo, claramente, que la explicación de que la Ciencia no trate de "la realidad" sino de "La Realidad" estribaba en que la primera sería, a juicio de García Calvo, heraclítea, la ontología originaria como verdadera realidad estará en el perpetuo devenir en el tiempo; mientras que la segunda, que sería de la que trata la Ciencia, consistiría en una cosificación y detención en el tiempo derivada de aquello que estaba en movimiento: «Si una ciencia, o una filosofía, que yo no distingo para nada (la verdadera filosofía que hoy padecemos es la Ciencia, y lo demás que se llama filosofía no son más que complementos, restos, accesorios), si una ciencia o una filosofía se empeña en tratar cosas como esas, pues ¿qué hace? Trata no de 'aquí', porque eso es imposible, pero trata de 'iel aquí!'. ¡Ah! Eso ya es un término filosóficon: 'el aquî'. Eso ya puede ser un término científico. Trata de 'el ahora'. De 'ahora' es imposible que trate. Para eso está la lengua corriente, pero el lenguaje de la ciencia no puede tratar de 'ahora'. Tratará de 'el ahora'. Pero 'el aquí' y 'el ahora', notadlo, se han convertido en realidades; por eso se puede tratar de ellas». Este anarquismo de raigambre heraclítea no está lejos de los infundables fundamentos de la postmodernidad actual, desde Heidegger y la conversión del ser como acontecimiento en el tiempo en los entes estáticos mundanos hasta Deleuze, Tony Negri o Giorgio Agamben; fuentes del anarquismo postmoderno radicado en la defensa de la indeterminación como espacio de la libertad.

Siguiendo el corolario de García Calvo, por tanto, la Psicología conductista, esas derivas skinerianas que se enseñan en las universidades actuales y se aplican

14 VVAA Antipsy-chologicum. Del papel de la psicología académica: de mito cientifico a mercenaria del sistema. Editorial Virus, Barcelona 2006. Agustín García Calvo "Que el yo no soy yo", págs.275-286. 
en las industrias contemporáneas son la forma como se estatifica lo viviente, la psyché, para tratarla como ánima, alma, la persona o el yo. Foucault y Deleuze mediante el movimiento de la antipsiquiatría se enfrentaron a la corriente principal, haciendo notar la salud del esquizoide y lo detestable de aplicar técnicas de reorientación del insumiso al rebaño. «El carácter (êthos) del hombre es su daimón» decía Heráclito en uno de sus famosos fragmentos. Y por eso frente al trabajo de la reconducción de la disidencia de nuevo a la masa y de la anulación de la anomalía mediante la incorporación de la normalidad, el libertarismo sesentayochista, con su énfasis en la indeterminación, ocasionó no pocos problemas sociales; como el que se desmantelase el sistema social de tratamiento psiquiátrico y los verdaderos locos (los enajenados graves) quedasen a merced de la familia o abandonados a la mendicidad. Estuvo bien denunciar el electroshock y la tortura, el encierro y la camisa de fuerza, pero al no proponerse claras alternativas tales remedios pudieron llegar a ser, en ocasiones, algo peor que la enfermedad.

Cuando Spinoza indicó que "toda determinación es negación" pretendía con ello que se constatase, sin nostalgia, la necesidad de reducción de la infinitud de los sucesos para llevar a cabo la labor del conocimiento; pero las lecturas que de tal pensador hiciese el postestructuralismo francés llevó a considerar que cualquier negación (palabra de resonancias hegelianas) debía de ser considerada como un crimen contra la realidad cuando no como una funesta hipocresía. Por eso García Calvo, el mejor anarquista español contemporáneo, explicaba en lenguaje corriente que la detención del flujo del tiempo y la unificación de la multiplicidad que habita en cada singularidad resultan momentos necesarios para la comprensión científica de la realidad: «La realidad está bruscamente fundada en la conversión de 'ahora'en 'un ahora'; 'el ahora', 'los ahora'. Está fundada justamente en esta reducción del tiempo que de verdad está pasando, que es inasible, incapaz de ser objeto de ninguna ciencia, en 'un ahora', 'el ahora' que ya son formas de realidad y que, por tanto, pueden ser objeto de ciencias de la realidad, de filosofías». Lo que Calvo indica con pesar, en lenguaje corriente, dispuesto a rendir culto y ser fiel a la indeterminación hasta el final; en oposición a toda ciencia y a toda filosofía; lo han reafirmado los pensadores del mayo francés, anticapitalistas y antiestatalistas, mediante las más diversas jergas de lenguaje científico o especializado.

El problema entonces estriba realizar un pensamiento que se queda en la negación de la negación, como teología negativa de culto a la preservación de 
una Nada, nihilista, que ocupó el lugar de Dios y del Hombre al morir ambos y que no propone la constitución de ningún mundo alternativo, viable y concreto, que pudiera oponerse y proponerse frente a lo vigente constituido. $Y$ eso ha sido pregnante socialmente porque semejante anarquismo postmoderno resulta, muy a menudo, exclusivamente individualista, sin siquiera mantener las consideraciones colectivistas del anarquismo clásico; manifestándose por tanto tan en contra del Estado (máquina burocrática de determinación) como en contra del Mercado (máquina económica de determinación) y a favor de que se deje todo en libertad. Tal postura ha ocasionado no pocas ambigüedades y confusiones, si bien a la hora de la verdad el mejor anarquismo postmoderno no ha podido menos que aunarse (como cuando Derrida escribe con Habermas, pese a sus distancias y diferencias) a unas fuerzas constituyentes socialistas (o socialdemócratas) frente a la amenaza imperialista del poder determinante y constituyente del imperialismo norteamericano y de la globalización en curso.

Las confusiones y ambigüedades residen en que el individualismo monadológico de un Stirner fusionado con la Ontología de Leibniz se ha convertido por el contrario a su necesario aggiornamiento de izquierdas a la hora de la verdad; se ha presentado, en numerosas ocasiones, como han denunciado Fredric Jameson, Terry Eagleton, Slavoj Zizek o Allex Callinicos, en la lógica cultural del capitalismo tardío, esto es, en la ideología del egoísta y egotista ciudadano singular de los países desarrollados. En una serie de doctrinas ideológicamente confluyentes con el neoliberalismo que predica la libertad, entendida como librecomercio en esa quimérica espontaneidad inexistente del mercado de Adam Smith, frente a la intervención social público-estatal. En tales momentos la planificación del mercado multinacional y su intervención globalizadota se imponen frente a la intervención estatal y la acción popular, esto es, en nombre de la libertad y la indeterminación se vende a las masas la ideología que lleva a la servidumbre voluntaria. Se alcanza la libertad dejando libre al mercado para convertirnos a todos en asalariados.

Ahora bien, contando con que el cierre aporético y escéptico no sea sino el síntoma de una patología colectiva cuyo diagnóstico debe ser el de nibilismo contemporáneo y que la puesta de la libertad en aquello que esclaviza pueda ser un síntoma de tal malestar en la cultura; estaríamos ante una enfermedad de la que cabe más de una curación y varios tratamientos simultáneos y complementarios. Lugo lejos de ver el cierre de todo acontecer y de toda posibilidad ante una pro- 
liferación de determinaciones omniabarcantes hoy podemos vislumbrar en el movimiento Anti-globalización de los países desarrollados un buen germen de política y creatividad, vivas, en el seno mismo de Occidente. Como también en la ampliación de la mirada más allá del etnocentrismo, pueden encontrarse una serie de buenas posibilidades de cambio y transformación social, mediante otros agentes de la historia. En la etapa revolucionaria que está afectando a América Latina con Venezuela a la cabeza y a Oriente Próximo con Irán a la cabeza, se puede todavía apostar por todo un programa de transformación del mundo establecido y por la subversión colectiva del dominio del capital global.

Además, tanto el programa de exigir un cumplimiento real (y no sólo hipócrita o formal) de la Ilustración, propio de la mejor modernidad - la que pretende que sean efectivos los Derechos Humanos y el Estado de Derecho-como el programa de enterramiento de la historia de Occidente en aras de un nuevo inicio con unos nuevos principios, propio de la mejor postmodernidad, siguen en vigor en agonística tensión. ¿Por qué tener que escoger entre una de esas dos grandes vías? Mantener ambas como complementarias nos deja con no pocas líneas vivas de pensamiento plural que se oponen en mayor o menos medida al ideario del imperio, a esa paradójica tesis del dominio global de un pensamiento único que, tanto la ideología dominante como el pensamiento derrotista se esfuerzan por declarar el mañana como cumplido y definitivamente clausurado.

En general la socialdemocracia encuentra la Ilustración parcialmente realizada y acabó admitiendo al capitalismo como agente de progreso, considerándolo compatible con la democracia y la reforma social en vías de la mejora colectiva. La Postmodernidad considera que la Ilustración es un totalitarismo que identifica con el principio de la soberanía monárquica y pretende tanto recuperar formas arcaicas abandonadas en las sendas perdidas del basurero de la Historia como replantear nuevos principios sobre los que pueda asentarse el diluido nuevo sujeto habitante de las macrometrópolis del mundo desarrollado. En curiosa hibridación entre el reformismo de los primeros y la revolución de los segundos existe una izquierda radical no postmoderna sino ilustrada, como la ejemplificada por Carlos Fernández Liria, que pese a reconocer que se vive bajo un totalitarismo, bajo la «dictadura del Capital»; aboga por la recuperación de los principios del Estado de Derecho y por una Democracia moderna congruente con los principios ya establecidos por la democracia clásica. De este modo se mantiene en ambos movimientos una cierta ambigüedad a la hora de determi- 
nar las acciones políticas mayormente adecuadas al diagnóstico de la situación. Si vivimos bajo una dictadura entonces hay que poner bombas y enfrentarse a la tiranía que nos es impuesta, sería el corolario inmediato que tendría que salir a la palestra, y, si no vivimos bajo una dictadura, entonces se puede promover la vía política parlamentaria u otras novedosas vías para cambiar el estado de cosas que se nos aparece tan indeseable. Sin embargo mientras que los anti-ilustrados postmodernos de izquierdas terminan planteando un estado de cosas de totalitarismo light al que enfrentar desde la micropolítica extraparlamentaria de adquisición de márgenes frente al poder como microrevolución constante; los pro-ilustrados de la izquierda extraparlamentaria admiten la mesopolítica de una revolución "armada pero pacífica» desde el esperanzador surgimiento de la revolución bolivariana en Venezuela. El punto en común reside en considerar que la macropolítica está plenamente en manos de las corporaciones económicas del tardocapitalismo, bien porque ha sido secuestrada, bien porque ha sido siempre así, bajo las distintas máscaras que ha adoptado la dominación para subyugar la libertad.

Luego el proyecto de la Ilustración en su sentido progresista que habría de superar la etapa de la revolución burguesa mediante un desarrollo y despliegue en la revolución comunista puede diagnosticarse como proyecto inviable, como un fraude o una ilusión de los que hay que despertar para construir un nuevo mundo bajo otros principios y sobre otras bases. $O$ también puede diagnosticarse como proyecto inacabado o como asignatura aún pendiente, quizás como un buen asunto que habría sido secuestrado por el mercado y del que habrá que pagar un cuantioso rescate; o incluso como una tradición con muchas fisuras que hay que corregir, con muchos elementos que habrá que transformar y con muchas nuevas aportaciones que habrá que añadir a lo que se quiera conservar del fondo intelectual de la historia de Occidente. En tal sentido esa postmodernidad que aboga por el pluralismo tendrá que contar con el paradigma moderno en cuanto uno más entre un amplio abanico de los mismos, so pena de violar de no hacerlo de este modo los principios que pregona, ofreciendo por su parte un nuevo marco común para todos ellos.

Fue en ese sentido que Gianni Vattimo ya en los años 80 del pasado siglo habló de la Hermenéutica (o paradigma de la multiplicidad de paradigmas) como la nueva lengua koiné (o común) por medio de la cual pudieran simultanearse y convivir varias formas de interpretar el mundo y la realidad sin que hubiese de prevalecer sólo una de ellas. El común denominador no apareció sin embargo 
con nitidez sino que quedó como un vago concepto al que habría que llenar de contenido. Ese contenido pensamos que lo han ofrecido los trabajos de otros grandes filósofos recientes, como los que Jacques Derrida dedicó a pensar y que pudieran ofrecerse como el fondo impolítico desde el que construir lo político.

Esos fondos son los que podemos sintetizar en una serie de puntos: 1. Ensanchar el espacio de lo posible como política de la deconstrucción 2. Acoger el acontecimiento, el evento, como motor singular de transformación de la forma, como apertura de por-venir. 3. Repensar el mesianismo tras la muerte de Dios, remarcando la importancia de la revolución en cada instante, en el aquí y ahora. 4. Habitar las aporías y las paradojas como final de la pretensión de gobernar los acontecimientos en su totalidad. 5. Poner de manifiesto como toda decisión entraña una responsabilidad irresponsable porque las reglas son cambiantes, luego sólo la justicia, más allá del derecho, la justicia indecible, no escrita, implica una responsabilidad plena e ineludible. 6 . Entender que negociarse con el negocio es la negación del ocio (nec-otium), luego con lo que hay que negociar es con lo nonegociable, realizando una lucha por salvaguardar algo de aquello que pudiera denominarse dignidad y sin lo cual nos venderíamos totalmente en el mercado. 7. Resistencia al Nuevo Desorden Mundial, al proceso de Mundialización, homogeneizador, atendiendo a la heterogeneidad y preservando y cuidando la diferencia y la pluralidad. 8. Tener claro que ya no es demócrata quien se manifiesta como tal, que el neoliberal es un nuevo totalitario, porque la democracia no está alcanzada, ni de lejos; sino que tal sistema de gobierno que Rousseau calificaba más propio de dioses que de hombres es una democracia por-venir, que desborda los límites del cosmopolitismo y su proclamación formal. Siendo ahora un principio de la democracia del siglo XXI no aceptar que la democracia no sea material y realmente efectiva, como lo ha sido durante la modernidad. 9. Derrida por tanto presentó lo indeconstructible como fondo sin forma de la deconstrucción, como materia indeterminada, en cuanto lugar que hace posible la tarea misma del pensar, espacio de libertad, porque si todo estuviese conquistado no sería posible el movimiento que se opone a la dominación. Hay que detectar de dónde surge la libertad, cuál es su fuente, para beber de ella. La deconstrucción se alimenta de lo indeconstructible, de lo inalienable. 10. Entender también lo indeconstructible y lo inalienable como fuente de la justicia, significa, que más allá del derecho positivo, bombardear Irak resulta injusto, con o sin mandato de la ONU (derecho). La sanción legal no otorga justicia sino que aporta cierta legitimidad. 11. El don, la hospitalidad, el perdón, la amistad, el amor, la amabili- 
dad,... la deconstrucción parte como análisis de los espacios inalienables hacia el desmontaje de los espacios de alienación. 12. El respeto por el secreto (resguardo de la intimidad y la singularidad de cada cual) y la aversión a la mentira (al engaño del otro y de uno mismo) serán dos elementos nutricionales o fuentes desde la que llevar a cabo la labor de reconstruir el mundo. 13. Lo inalienable, la justicia, el amor a la verdad y la empatía para con los demás se coimplican en armonía preestablecida y crecen o decrecen simultáneamente.

Será siempre entonces desde lo inalienable, desde lo mayormente resistente a la desertificación, al vaciamiento del capitalismo o de cualesquiera otras fórmulas de sujeción y dominación que se puedan detectar; desde donde podrá hacer pié cualquier pensamiento comunista que se quiera aceptable de nuevo en el marco de las propuestas de transformación de la realidad en el sentido de una mejora del mundo en que vivimos. Lo inalienable no consiste en el mantenimiento de una teología negativa de adoración de la Nada salvífica, la grieta, lo inefable, lo indiscernible, lo indisponible, lo abismático, lo caótico, lo indeterminado, en definitiva, que ya se defiende muy bien ello solito; sino que son espectros concretos, como el amor, la amistad, la hospitalidad, la amabilidad, el don, la generosidad, etcétera, una serie de virtudes de las que ya nadie quiere hablar pero que alientan en las tradiciones de los libros clásicos que seguimos leyendo.

La síntesis disyuntiva entre las dos grandes tradiciones de Occidente, la de Platón y la de los poetas, lleva a la armonización del superhombre de Nietzsche con el hombre nuevo del comunismo, a la comunidad entre la tierra de la que hablara Heidegger y el mundo comunista pretendido por Marx. El comunismo acontece cuando se disuelven finalmente las más graves contradicciones: entre mundo y tierra, entre leyes y costumbres culturales, entre lo universal y lo particular, entre explotadores y explotados, entre ricos y pobres, contradicciones que están destruyendo nuestro ecosistema; acontece cuando finaliza tanto la oposición entre el hombre de ciencia y el hombre de letras como la separación de lo manual y lo intelectual. Por eso ese mundo no debe ya situarse en un espacio y un tiempo cronológico impreciso para llegar al cual habría que realizar una odisea de sufrimiento infinito y de lucha interminable, sino que el mundo-tierra del comunismo resulta mortal-inmortal y acontece en el aquí y ahora de todas las acciones excelentes del pasado, presente y futuro. En España, los trabajos herederos de Deleuze, Heidegger, Vattimo y Gadamer en Ontología estética y política, desarrollados por el incipiente pensamiento trágico de Teresa Onate, se han 
esforzado en poner de manifiesto lo esencial de la diferencia que el tiempo imprime en el ser; a fin de lograr la reproposición del lema nietzscheano según el cual, los griegos, siendo una cultura trágica, no fueron pesimistas. La jovialidad griega no se amilanaba por la muerte porque concebía la eternidad, siendo un fatídico destino el que ha situado a Occidente en la senda del nihilismo y en la negra pérdida de esa alegría que, los hijos de Nietzsche, llegaron a atisbar.

Lo que se opone entonces a la antecedente acción política e intelectual es el derrotismo heredado en Europa tras el triunfo del capitalismo, la caída del muro de Berlín, la victoria franquista en la guerra civil española y las desviaciones de las propuestas de constitución de un mundo nuevo hacia la generación de aberrantes sistemas de poder y de dominación. Por eso ahora un Nihilismo, un nuevo existencialismo leninista, que de la mano de la izquierda radical recorre Europa. Su espectro reside en caracterizar que fascismo y totalitarismo son tanto el nazismo y los campos de concentración, el comunismo y el Gulag, como la socialdemocracia europea y el neoliberalismo anglosajón, todos son la misma cosa; algo que se dictamina desde el único lugar incontaminado del planeta, la izquierda radical. Lo que extraña es que si el capitalismo socialdemócrata es fascismo, y tan fascismo o más, mucho más (dada la subsunción real y la televisión) que nazismo y comunismo, se critique al proyecto del Estado del bienestar europeo, apelando a la libertad y se olvide tematizar la igualdad. Si el Derecho que no es sino la derivación enmascarada del poder del Estado y el Estado de derecho según Agamben no es sino la servidumbre voluntaria de La Boetie que amenaza a esa gente común que se sueña protegida por la institución que tan sólo los oprime, entonces la Revolución francesa puede ser pasada por alto y el estado de la politica no será ya el contractualismo y el pacto social de un Rousseau, Hobbes, Locke o Kant; sino que el estado de la política seguirá anclado en el modelo de la soberanía que dirigió el Antiguo Régimen. Por el contrario, Jacques Derrida, conjuraba en 1993 al espectro de Marx surgido a partir del contractualismo ilustrado y de los derechos humanos burgueses para reinventar el comunismo, luego no todos los postmodernos puede decirse que hagan como si la modernidad no hubiese existido o como si, lejos de las discontinuidades que defienden, hubiese una continuidad desde los regímenes soberanos y arcaicos con la actualidad.

Como también se nos dice desde Debord y el situacionismo que al fin y al cabo todo es espectáculo, siendo el poder-fascismo, hoy, igual a televisión, que pone y quita leyes y gobernantes a su antojo, lobotomizando exciudadanos sur- 
ge la dificultad de dirimir lo que es real y lo que es apariencia. $Y$ desde luego que la televisión pública es nefasta, pero no es el Apocalipsis, eso es exagerar un poquito, pues a pesar de la televisión siguen habiendo buenos poetas, músicos y escritores, pintores y profesionales, obreros y amas de casa que cuidan de sus niños, pese a la televisión basura, que desde luego es nefasta; si bien no es ya tan nefasto el poder escuchar una película en nueve idiomas con un DVD o disfrutar de la música clásica por la radio, por mucho que la técnica y su desarrollo amenace heideggerianamente a la humanidad con su transformación en Ciborgs periféricos de la máquina de guerra deleuziana.

La Nostalgia por la Revolución del 68, ante lo que no era más que una diversión de los niñatos burgueses que iban a la universidad, mientras esperaban para ocupar el sitio de papá; la indiferencia ante la Revolución francesa y el rechazo de la Revolución Rusa, llevan a la izquierda radical a este anarquismo difuso que estamos criticando e incluso descalificando ${ }^{15}$. Pero es que hay que aprender de la Ética de Spinoza cuando nos dice que "cuando el alma imagina su impotencia, se entristece ${ }^{16} "$ y desarrollar un proyecto constructivista de Estado socialista viable, en consonancia con la mejor Ilustración y con las rectificaciones que se imponen desde la mejor Postmodernidad; la que hace pié en la afirmación de la existencia antes que en el nihilismo consumado.

Toni Negri lo sugiere en una entrevista, muy spinozisticamente, al declarar que la gente sufre en el Occidente desarrollado porque no se hace consciente de su propia potencia, mientras que en el Tercer Mundo no se sufre, se es un animal; luego no podemos ser los sufridores natos de la intelectualidad europea, los existencialistas vestidos de negro, malos calcos de Sartre y de Camus, fascinacinados por el Horror, como fans incondicionales del coronel Kurtz de El corazón de las tinieblas de Conrad, tan acertadamente llevado al cine por Coppola. Sobra entonces la constatación de que vivimos en un campo de exterminio. Vivimos es mucha gente, no hay que usar el plural, pues hay muchas diferencias en el vivir ya en Occidente, entre la vida material que lleva un catedrático de universidad, la que llevan las marujas de Aravaca y de los chalets adosados; frente la que llevan los que trabajan en la construcción y la agricultura, los que laboran de camareros, o

15 Véase mi breve noticia: «Enfrentarse al poder sin tomarlo y tomándolo». En:

http://www.bandera.org/articulo.php?articuloID $=461$

16 Baruch Spinoza Ethica demostrata more geometrico, 3PLV. 
de telefonistas de Terra. En el propio Occidente no es la misma vida la de los que viven trabajando 12 horas diarias tras la barra de un bar, levantándose a las 6 de la mañana y metiéndose en el metro atestado de gente que la que viven los que trabajan en la función pública de nivel medio y alto. Las clases sociales existen aún $y$, el capitalismo, hay que reconocerlo, ha extendido la clase media en los países desarrollados hasta el punto de desarticular todo el movimiento obrero de Occidente.

El deber del intelectual es pensar para proponer, construir y constituir nueva realidad y ese vitalismo y afirmatividad es el que tiene que regir las intenciones y motivaciones del analista político, por eso dice Spinoza en su Ética que «el alma se esfuerza en imaginar sólo aquello que afirma su potencia de obrar», para dejar claro que no se trata sólo derribar y destruir, ni de reconstruir sin constituir. El hombre además de un ser depredador es también y con la misma profundidad ontológica, un ser placentario, constatación que permite a Sloterdijk en su Esferas I, reivindicar lo natal sobre lo mortal y el maravilloso hecho de ser nato en lugar del vitalismo existencialista de ese ser para la muerte arrojado a la existencia sin haberlo querido y en circunstancias que no ha elegido.

De ahí que Sloterdijk sea un especialista en Nietzsche, pues su trabajo actual estriba en invertir el existencialismo nihilista y desarrollar el tema nietzschiano por excelencia de la afirmación de la existencia. Con Nietzsche y Heidegger en la mano, con tal de no caer en el derrotismo fatalista, se puede obrar intelectualmente a favor de la constitución de un mundo más justo, aunque sea desde el decálogo del espíritu libre anarquizante, propuesto por Nietzsche, que exponemos a continuación:

«Los diez mandamientos del espíritu libre.

Tú no amarás ni odiarás a los pueblos.

Tú no te dedicarás a la política.

Tú no serás rico, ni tampoco mendigo.

Tú evitarás a las gentes célebres e influyentes.

Tú tomarás mujer de otro pueblo distinto del tuyo.

Tú harás educar a tus hijos por tus amigos.

Tú no te someterás a ninguna ceremonia de la Iglesia.

Tú no te arrepentirás de un error, sino que realizarás en compensación una buena acción de más. 
Tú preferirás, para poder decir la verdad, aceptar el exilio.

Tú dejarás, por lo que a ti respecta, que el mundo actúe a su antojo, y harás lo mismo con respecto a é $\left.\right|^{17}$ \%.

$Y$ no es semejante vitalismo incongruente con una acción política constructiva o con el pensamiento político de Spinoza, todo lo contrario, porque a decir del filósofo marrano en su Ética «un hombre libre en nada piensa menos que en la muerte, y su sabiduría no es una meditación de la muerte, sino de la vida ${ }^{18}{ }^{\prime}$; luego alguna diferencia habrá entre un individualismo existencialista de altura que reivindica el espacio de lo impolitico frente a la tentación de politizar todo lo existente y el individualismo del liberalismo y el neoliberalismo. Lo que ocurre es que las derivas de las fuentes de pensamiento anti-ilustrado del romanticismo alemán, curiosamente, han acabado rentando para un individualismo apolítico postmoderno demasiado congruente con el consumidor culto y elitista del neoliberalismo imperante. La procedencia generacional de los pensadores de la postmodernidad actual es la que les ha impreso el registro de manifestarse tanto más contrarios a la sociedad de masas cuanto más cómodos e insertos se han ido encontrando en ella. Son intelectuales como Agamben o Negri los que tienen cierto que vivimos bajo un totalitarismo y los tienen claro también que la verdadera vida está en las favelas de Río de Janeiro entre los pobres o en los campos de concentración; mientras habitan en palacios y se codean con la sociedad opulenta y enriquecida que pasó de la rebeldía juvenil a ocupar el poder.

La revolución estudiantil del sesenta y ocho no fue una revolución real, porque las revoluciones reales no se limitaron a destruir la literatura del orden anterior existente sino sobre todo a construir realmente lo pensado y debatido en la intelectualidad. No puede negrianamente decidirse por preservar la fuerza de lo constituyente mediante la operación de romperlo todo y no reemplazar nunca sino que hay que tener el valor de constituir un mundo, una persona, una sociedad, una comunidad, una amistad. Los anti-Todo agustín-garcía-calvistas pueden llevar a cabo un importante papel de destrucción pero se quedan en ese momento ante el vértigo que provoca la más importante tarea simultánea de la reconstrucción.

\footnotetext{
${ }^{17}$ Friedrich Nietzsche Fragmentos póstumos (1876-1878), 19[77].

${ }^{18}$ Baruch Spinoza Eth.4PLXVII.
} 
Si la cuestión es si cabe que un intelectual sea nihilista y misántropo, no hay duda de que la opción de Ciorán está al alcance de cualquiera con ingenio y ganas de explorar lo aporético, paradójico y oscuro de la existencia. La pregunta más compleja es si se puede ser otra cosa, visto a que ha reducido el siglo XX a los intelectuales. Y no se trata de que el intelectual no pueda cambiar la totalidad de las cosas, y deba conformarse con parcelas más limitadas, porque nadie puede más que eso, de lo que se trata es simplemente constatar que cualquier anuncio de coche vale más que cien artículos a efectos de movilización social. Cuando uno constata eso, poco resta excepto el escepticismo o sus variedades cínicas o nihilistas. ¿Pero puede el intelectual llevar a cabo su labor sin atender a los efectos de movilización social que genera? Diríamos que puede y debe, ya que las repercusiones de las actividades intelectuales no son fáciles de calibrar. Cervantes realizó el Quijote, Van Gogh sus cuadros, sin contar con la repercusión social, ni siquiera con la económica. Otra cuestión es que se mueran de hambre los intelectuales independientes, asunto trágico y lamentable, pero la constructividad y las ganas de vivir son lo único que puede impulsar la acción social. Quizás es porque no hay artículos que sean verdadera dinamita que da la impresión de que no supera un poema actual a mil anuncios de coches a efectos de movilización social.

La idea de intelectual comprometido, dirigidor y orientador de las masas, afortunadamente, ha desaparecido, ya que era realmente una idea paternalista y elitista, además de demasiado pretenciosa. No se trata de que el intelectual piense por los que no piensan y les guíe por el buen camino, sino de que la mayoría llegue a ser capaz de pensar. Pero para ello lo fundamental es que haya pensamiento y la labor del pensador es producirlo. No basta con la educación escolar, sino que son los ciudadanos los que se enseñan a pensar entre sí, a través de la conversación, en polémica agonística, esto es, fructifera. Por eso el intelectual no tiene más que cumplir con su tarea de ciudadano y, de ese modo, exigir a los que lo rodean que la cumplan igualmente.

Desde traducir a Benjamin al español hasta escribir Ser y Tiempo; escribir en el País y militar en la plataforma ¡Basta ya! o escribir la Crítica de la Razón Dialéctica, junto a novela y teatro, militando a favor del comunismo y rechazando el premio Nobel; escribir novelas en gallego y defender a Castro o servir a los intereses de la Iglesia católica como erudito neotestamentario, también hay una multiplicidad de posibilidades de detentar una labor intelectual. Se puede ser 
intelectual orgánico o independiente, trabajar en favor de un sector y una ideología o de otro. Desde luego si el papel del intelectual fue algún día el de cambiar el mundo en su totalidad, como el del mítico Jesucristo, afortunadamente, ya nadie pretende tanto.

También está el que acaba por militar en favor de la religión y cosas semejantes, como lugares de producción de subjetividades alternativas a las de la servidumbre voluntaria o la esclavitud satisfecha. Ahí está Roger Garaudy. Pero en la configuración de las conciencias humanas operan demasiadas cosas además de la funesta televisión, cosas que cuenta Freud y cosas que cuentan los antropólogos, además de las que cuenta Marx y además de las ciencias, las artes y el pensamiento en general.

Propuestas constructivas como la Tasa Tobin, el Basic Income, los Microcréditos, el Tribunal Internacional de Justicia, junto a iniciativas semejantes, son aceptables para modificar el estado de cosas vigente. Pero si lo que se espera es una propuesta de salvación universal, a falta de la cual toda propuesta constructiva ha de ser descartada como reformismo humanista, desde luego que ninguna cumple con el requisito, pues al igual que la ONU, no sirven de mucho a nivel universal, aunque los 20 millones de refugiados que reciben ayuda de la ONU (ACNUR) creo que no estarán de acuerdo con los de las propuestas globales o nada, en que de igual. No da igual tampoco vivir bajo el régimen político de Pinochet que bajo el régimen político de Margaret Thatcher, el primero era una dictadura, el segundo una monarquía parlamentaria conservadora, iy ambos capitalistas! El capitalismo puede, como cualquier sistema económico, soportar distintos sistemas de organización política, igual que el esclavismo en Grecia soportaba la democracia ateniense o la oligarquía Espartana, junto a la monarquía teocrática persa o egipcia. Bien mirado, en Occidente, y por eso barrió a la URSS, no triunfó el capitalismo más que a medias (aunque ahora avance con el desmantelamiento del Estado del bienestar), ya que el sector público aunque no nos guste palió y sigue paliando considerablemente los efectos perversos del capitalismo salvaje.

No parece que dé igual el que haya puestos laborales públicos además de los privados a que haya sólo privados. ¿Que nuestro ocio de occidentales consumistas surge a costa de que otros sean esclavos? ¡De acuerdo completamente! Lo que se comprenderá fácilmente es que los ciudadanos de Atenas no van a renunciar 
a la ciudadanía y convertirse en esclavos para ser todos iguales, todos esclavos, sino que, más bien, tendrán que trabajar para que la mayoría (y no una minoría) puedan alcanzar la condición de ciudadano libre. Hablamos de Atenas porque allí estaba claro lo de libres e iguales a diferencia de los esclavos, en nuestro tiempo ya no tanto, pero cuando Hannah Arendt pone esto de manifiesto resulta patente que ella y los de su clase social no pertenecen a los esclavos, ni a los de dentro, ni a los de fuera.

Ahora bien, si no se puede lograr una cota de igualdad a un nivel digno de vida entonces no hay que ser favorable a la igualdad, sino esclavista griego, como Platón y Aristóteles, y sin reparos morales cristianos. Pero parece que hoy día el desarrollo tecnológico permitiría universalidad al menos el sustento básico, frente a otros modos de producción menos productivos. Luego no es la situación real tan desfavorable como se quiere a veces hacer creer al mundo.

Ciertamente ninguno de los sistemas de organización político-social fueron ni son la panacea, el Paraíso, pero no da igual uno que otro, no es todo la misma basura y conviene hacer distinciones y matizar las opciones.

Por mi parte considero que un intelectual ya hace una buena labor que vuelve la vida más digna de ser vivida para mucha gente cuando escribe un libro edificante, cuando realiza literatura, poesía, música, escultura, pintura, e incluso filosofía, cosas que no van a quitarle el hambre a nadie que lo padezca (para quitar el hambre lo mejor es producir comida, la agricultura o distribuir mejor la mucha que ya se produce, cosa de la política), pero leer al menos le va a quitar la estupidez a los que ya comen (a los que ya comemos), proporcionando la mayor calidad de vida alcanzable, la de la vida buena; que es no sólo la de la supervivencia animal sino la del cultivo de la sensibilidad (arte, música y literatura) de la corporalidad (deporte) y de la razón (ciencia y filosofía). No todo intelectual tiene que tener vocación política, aunque puede que todo arte sí que tenga consecuencias políticas.

El cultivo de las artes y las ciencias no garantiza sobrepasar la existencia biopolíticamente dirigida de la nuda vida, así como la dedicación para la subsistencia a las labores manuales tampoco implica una condena a la existencia meramente animal. El trabajo del intelectual también entra dentro de la categoría de producción y si se reduce a una labor asalariada en lugar de convertirse en una 
labor realizada con la finalidad de la mejora particular y la mejoría colectiva, entonces, no hay en ella ninguna diferencia entre otro valor de cambio cualquiera.

En realidad, siendo más precisos, el trabajo filosófico difícilmente podrá ser considerado como valor de uso o valor de cambio, porque en último caso nunca sería un bien (manufactura) sino un servicio, por eso es preferible una categoría griega para definirlo en su esencia, a riesgo de anacronismo, diciendo que el trabajo del intelectual es póiesis (creación), no téchne (manufacturación) y que característico de la creación (para la cual, muchas veces, es necesaria una previa destrucción) es la propuesta de ciertas alternativas o de, al menos, de ciertas claves para orientarse hacia las nuevas alternativas. En esto no se caería más que en un elitismo intelectual como el aristocratismo platónico si se diferenciase entre trabajo manual y trabajo intelectual definiendo el primero como el de los brutos y el segundo como el de los humanos. La labor intelectual del pensador asalariado que concibe su quehacer como un trabajo burgués cualquiera es tan bruta como la labor del más mezquino ganapán, que no se da cuenta del arte que entraña su labor manual sino que tiene al igual que el mal sofista, como único objetivo de su existencia y de su labor, la percepción de un dinero.

Lo curioso es que el capitalismo pague a intelectuales a sueldo para decir que todo está perdido, que ha finalizado la Historia, que todos los héroes han muerto, que ya sólo cabe asistir al Apocalipsis o conformarse con lo que hay. Para tales diagnósticos sobran los intelectuales, ya que semejante punto de vista lo conoce perfectamente todo televidente futbolero de los que se hacinan en el metro a las seis de la mañana. Por eso tanto el hombre alienado como el que no lo está se resisten a pensar y prefiere vivir dormidos a despiertos, es un mero instinto de supervivencia, un mecanismo de defensa del ego. Nadie puede soportar psíquicamente cargar en su conciencia con todas las atrocidades del planeta. Pero semejante perspectiva la conocen mejor que nadie, menos espectralmente y más corporalmente los que de verdad se mueren de hambre y enfermedad en África y Asia, ya que ellos no están esperando a asistir al advenimiento del Apocalipsis sino que lo están viviendo, día a día, por nuestra culpa. Y no sólo cuando los mass media lo narran sino incluso en este momento, como lo vivieron antes de ellos innumerables desgraciados a lo largo de la Historia de la Humanidad. La responsabilidad contraída por el pasado y la responsabilidad frente a las generaciones futuras está lejos de ser admitida por cada miembro del mundo Occidental triunfante, pero no por egoísmo e insolidaridad, sino porque no 
resulta soportable el día a día y harían falta unas espaldas de Atlas para además de resistir con empeño al derrumbamiento y promover en la medida de lo micropolíticamente posible la mejoría del planeta, tuviera que tener el heroísmo de ser soportar el peso de todos los pecados del mundo. Es desde los aciertos del mundo, desde el triunfo de la vida y desde los logros de la sociedad, no desde sus contrarios, desde donde se puede seguir construyendo. Lo fundamental es hacerse con un lugar desde el que irradiar lo que se siembra, no perderse entre el malestar de lo irradiado de manera nefasta, pues mientras lo primero fortalece, lo segundo debilita.

Ahora son mil millones de personas las que viven sin agua potable en el planeta, esto es, una de cada seis. Pero no hay que olvidar que cinco de cada seis personas en el mundo si que disponen de agua potable, merced a los avances en materia de tratamiento de la energía hidráulica y de la cloración del agua. No puede saberse si conseguiremos algún día que una mayoría del planeta podamos vivir dignamente e incluso lograr participar en las acciones políticas y decidir nuestro destino pero, desde luego, no da igual que coman unos millones más o unos millones menos, que se trabajen 40 horas semanales, 35, 15 o 10, que haya subsidio de desempleo y becas o que no los haya, con independencia de si se subvierte totalmente el sistema capitalista y desaparece o si tan sólo se le logra detener, maquillar, frenar y controlar, mediante reformas encaminadas a paliar sus efectos perversos, un régimen de vida que consideramos nefasto. Por eso hay que aceptar y laborar tanto en la reforma como en la revolución, al menos si se quiere analizar la realidad social con rigor y proponerse acciones políticas constructivas.

El capitalismo censura todo lo que no es él, si no puede acallarlo, lo denigra, lo margina y procura despotenciarlo, por ejemplo, ahogando económicamente cualquier intento en su contra, llegando sólo en los escasos casos en que algunos escapen a sus manos y eludan la férrea aquiescencia a priori exigida, a emplear métodos de exterminio y ahogamiento más expeditivos. Todo el espectro de lo público es un baluarte socialista desde el que resistir al empuje globalizador neoliberal y como tal hay que defenderlo

Por eso decíamos antes que el capitalismo en relación con las tareas intelectuales ni conoce el librepensamieto, ni consiente la verdadera crítica de lo establecido, no admitiendo las dinámicas ideológicas que no puedan encasillarse y 
clasificarse en determinados grupos de presión, esto es, sólo permitiendo las existentes en tanto en cuanto no amenacen al sistema establecido y respondan a esclerotizados repartos de la tarta del poder.

Por eso el control social es un Jano bifronte, porque por un lado puede ser positivo y permitir la intervención social, pero por otro puede ser negativo y promover la dominación y la explotación. El lado positivo del control social estriba en la propuesta que desde Grecia a nuestros días ha apostado por la instauración de un gobierno y unas leyes racionales para procurar el bienestar de las ciudades. El lado negativo del control social reside en el dominio que desde el origen de la política han querido procurarse unos pocos para subyugar y explotar a los muchos. Pensar la libertad como omnipotencia y determinar su imperio como la supremacía de quienes, como dijera Platón en Las Leyes (687a-e), acumulan fuerza y poder exclusivamente para la satisfacción de sus deseos, favorece tan sólo al lado negativo del control social. Mientras que pensar la libertad como limitada por la de los demás y por la racionalidad, como le dijera a Platón su interlocutor en la misma obra citada: «Ya entiendo lo que quieres decir: me parece que afirmas que no se ha de pedir ni instar a que todo se conforme a la propia voluntad, sino que esa voluntad se acomode aún en mayor grado a la propia razónn; estrategia que favorece la creación de ciudades en la que se procure el bienestar ciudadano en lugar de la forja de espacios de lucha entre voluntades de poder. A los deseos de la voluntad se oponen aquí los principios de la sensatez como al principio de realidad se opone el principio del placer.

La historiografía y la filología modernas y contemporáneas han opuesto en numerosas ocasiones la Grecia individualista de los sofistas y la socializante de Platón. Sin embargo, cuando en Occidente se toma el modelo de la antigüedad greco-latina, es evidentemente, desde una posición hermenéutica que siempre se idealiza y que siempre comete anacronismos. El paradigma político del mundo occidental no está en el pasado sino que es una mirada retrospectiva que redondea los rasgos antecedentes para proponer objetivos que alcanzar en el futuro y tesis que defender en el presente. Así, el joven Nietzsche, al escribir sobre $L a$ mujer griega y sobre El Estado griego en 1871 vería intempestivamente a la antigüedad clásica como una sociedad protosocialista altamente cohesionada, en la que «el individuo lo recibía todo del Estado, para luego devolvérselow. Los griegos a su juicio serían "los hombres políticos por excelencia" a causa precisamente «de la grandeza de su arte» que habría demostrado «la subordinación de todos 
los demás intereses al interés del Estado», de tal modo, que el gran arte, el arte sublime o la tragedia apolíneo-dionisíaca, habrían surgido del suelo nutricio de la ciudad griega; erigido sobre la tierra para recrear un mundo a imagen y semejanza del cosmos de los dioses. Con tales aseveraciones discrepará Hannah Arendt al hablar de la cohesión de la primera democracia. El Estado prusiano, mil veces vilipendiado por Nietzsche, la segunda guerra mundial, el nazismo y el caso Heidegger, no podían dejar intacta la idealización griega del Romanticismo, por lo que para la Hannah Arendt de La condición bumana (1958), la ciudad-estado de los griegos era «el cuerpo político más individualista y menos acorde de los conocidos por nosotros", una sociedad protoliberal escasamente cohesionada en la que el individuo sería la medida de todas las cosas. La discrepancia entre ambos es notoria y la falacia anacronista, si bien inevitable en toda referencia a la antigüedad, la comete mayormente Hannah Arendt, ya que el filósofo de la tragedia, como indicara en sus cursos de Retórica del semestre de invierno de 1872 en Basilea; los primero que explicó a sus alumnos fue que «la conciencia de la dignidad individual es romana, no griega».

En Heidegger, como en el Esquilo, es la propia tierra natal (Heimat) -una vez abandonado el pueblo tribal (Volk) debido a las resonancias nacionalsocialistasla que se personifica en un actor colectivo, al igual que la obra de arte, superada ya la teoría del genio y defendiendo la necesidad de poseer raíces. De ahí una las muchas dificultades para dar del todo el visto bueno a un anarquismo heideggeriano a lo Schürmann que haga hincapié en el individualismo existenciario del Dasein o al libertarismo derivable del nomadismo rizomático de Deleuze.

Fue el pensamiento postmoderno francés entre los años 68 a 80 del pasado siglo se encargará de resituar a Nietzsche y a Heidegger en otro paradigma lejos tanto de las responsabilidades ideológicas que se les achacaron tras el conflicto bélico mundial como de las derivaciones neoconservadoras de sus respectivos pensamientos; forjándose entonces tanto una nueva interpretación de su filosofía como una nueva lectura de la antigüedad clásica, siendo subsidiaria la segunda de la primera.

Una nueva lectura de Marx está tan pendiente como en curso pues no puede estar nunca acabada. Si bien Deleuze pretendía realizar un libro sobre Marx antes de abandonar la filosofía por la pintura cuando le alcanzó la muerte. En su lugar, fue en 1993 cuando Jacques Derrida pretendió corregir los infortunios del 
marxismo en "Espectros de Marx» conjurando a Max Stirner para, de la mano de éste, abordar el espectro de un comunismo en el cual, socialismo e individualismo, no se opusieran en dialéctica maniquea. Algo semejante realizó Toni Negri en el paso de milenio cuando en su Imperio (del año 2000) acuñó el término "multitud de singularidades", en el cual, la multitud maquiaveliana y la singularidad spinozista habrían de darse la mano fundiéndose en una síntesis disyuntiva entre contrarios pero no opuestos. Todo ello para así romper con la oposición entre lo individual y lo colectivo, en pro de una noción de lo primero alejada del egotismo narcisista y de una noción de lo segundo alejada de la perdida de la individuación. La pérdida de la individuación romántica ocasionada por la voluntad schopenhaueriana sería proclive a la aventura nacionalsocialista, mientras que la pérdida de la particularidad ilustrada en aras de la universalidad cosmopolita sería proclive a la aventura del capitalismo mundial. Esos dos peligros estarán siempre presentes y será necesario conjurarlos y evitarnos mediante todos los mecanismos de limitación del poder que puedan llegar a arbitrarse. 